\title{
MELTING CONDITIONS OF GRANITOID XENOLITHS IN CONTACT WITH ALKALINE MAFIC MAGMA (GUSINOOZERSKAYA DYKE, WESTERN TRANSBAIKALIA): TO THE PROBLEM OF THE ORIGIN OF ULTRAPOTASSIC ACID MELTS
}

\author{
V. B. Khubanov ${ }^{1,2}$, T. T. Vrublevskaya1,2, A. A. Tsygankov ${ }^{1,2}$, A. G. Vladimirov 3, 4, 5, \\ M. D. Buyantuev ${ }^{1}$, E. N. Sokolova ${ }^{3}$, V. F. Posokhov' ${ }^{1}$, E. A. Khromova ${ }^{1}$
}

${ }^{1}$ Geological Institute, Siberian Branch of RAS, Ulan-Ude, Russia

${ }^{2}$ Buryat State University, Ulan-Ude, Russia

${ }^{3}$ V.S. Sobolev Institute of Geology and Mineralogy, Siberian Branch of RAS, Novosibirsk, Russia

${ }^{4}$ Novosibirsk State University, Novosibirsk, Russia

${ }^{5}$ Tomsk State University, Tomsk, Russia

\begin{abstract}
The alkaline mafic (lamprophyric) Gusinoozerskaya dyke in West Transbaikalia is composed of partially melted granite xenoliths. Among the xenoliths, two melted substrates are observed: (1) plagioclase and quartz, and (2) alkaline feldspar and quartz. Few millimeters thick microfelsite and microgranophiric rims are the products of melting around the granite xenoliths. Ultra-acid glass is observed in the inner parts of the xenoliths at the boundary of quartz and feldspars. A distinctive feature of the fresh melts (regardless of the composition of the protolithic substrate) is an increased content of potassium with $\mathrm{K}_{2} \mathrm{O} / \mathrm{Na}_{2} \mathrm{O} \geq 2$. Having compared the compositions of the products of contact melting with the experimental data, we conclude that melting took place in the presence of alkaline-chloride and/or alkaline-carbonic fluid released from the crystallizing host alkaline-basic magma. The probable geotectonic conditions for the occurrence of ultrapotassic acid magmas are estimated.
\end{abstract}

Key words: alkaline mafic magma; calc-alkaline lamprophyre; granitoid xenoliths; contact melting; ultrapotassic acidic melt; petrogenetic and tectonic conditions; Gusinoozerskaya dyke; Transbaikalia

\section{RESEARCH ARTICLE}

Received: October 20, 2016

Recommended by E.V. Sklyarov

For citation: Khubanov V.B., Vrublevskaya T.T., Tsygankov A.A., Vladimirov A.G., Buyantuev M.D., Sokolova E.N., Posokhov V.F., Khromova E.A., 2017. Melting conditions of granitoid xenoliths in contact with alkaline mafic magma (Gusinoozerskaya dyke, Western Transbaikalia): to the problem of the origin of ultrapotassic acid melts. Geodynamics \& Tectonophysics 8 (2), 347-368. doi:10.5800/GT-2017-8-2-0245.

Для цитирования: Хубанов В.Б., Врублевская Т.Т., Цыганков А.А., Владимиров А.Г., Буянтуев М.Д., Соколова Е.Н., Посохов В.Ф., Хромова Е.A. Условия плавления гранитоидных ксенолитов в контакте со щелочно-базитовой магмой (Гусиноозерская дайка, Западное Забайкалье): к проблеме происхождения ультракалиевых кислых расплавов // Геодинамика и тектонофизика. 2017. Т. 8. № 2. C. 347-368. doi:10.5800/GT-2017-8-2-0245. 


\title{
УСЛОВИЯ ПЛАВЛЕНИЯ ГРАНИТОИДНЫХ КСЕНОЛИТОВ В КОНТАКТЕ СО ЩЕЛОЧНО-БАЗИТОВОЙ МАГМОЙ (ГУСИНООЗЕРСКАЯ ДАЙКА, ЗАПАДНОЕ ЗАБАЙКАЛЬЕ): К ПРОБЛЕМЕ ПРОИСХОЖДЕНИЯ УЛЬТРАКАЛИЕВЫХ КИСЛЫХ РАСПЛАВОВ
}

\author{
В. Б. Хубанов 1,2 , Т. Т. Врублевская 1,2 , А. А. Цыганков 1,2 , А. Г. Владимиров 3 , 4, 5, \\ М. Д. Буянтуев ${ }^{1}$, Е. Н. Соколова ${ }^{3}$, В. Ф. Посохов ${ }^{1}$, Е. А. Хромова ${ }^{1}$ \\ ${ }^{1}$ Геологический институт СО РАН, Улан-Удэ, Россия \\ 2 Бурятский государственный университет, Улан-Удэ, Россия \\ ${ }^{3}$ Институт геологии и минералогии им. В.С. Соболева СО РАН, Новосибирск, Россия \\ ${ }^{4}$ Новосибирский государственный университет, Новосибирск, Россия \\ 5 Томский государственный университет, Томск, Россия
}

\begin{abstract}
Аннотация: Щелочно-мафическая (лампрофировая) Гусиноозерская дайка (Западное Забайкалье) содержит гранитные ксенолиты, испытавшие частичное плавление. Среди ксенолитов выявлено два субстрата, претерпевших плавление: 1) плагиоклаз и кварц и 2) щелочной полевой шпат и кварц. Продукты плавления представляют собой микрофельзитовые и микрогранофировые оторочки вокруг гранитных ксенолитов мощностью в первые миллиметры. Во внутренних частях ксенолитов на границе кварца и полевых шпатов наблюдается ультракислое стекло. Отличительной особенностью новообразованных расплавов, независимо от состава протолитового субстрата, является их повышенная калиевость с отношением $\mathrm{K}_{2} \mathrm{O} / \mathrm{Na}_{2} \mathrm{O} \geq 2$. $\mathrm{Ha}$ основе сопоставления составов производных контактового плавления с экспериментальными данными показано, что плавление происходило в присутствии щелочно-хлоридного и/или щелочно-углекислого флюида, выделявшегося из кристаллизующейся вмещающей щелочно-основной магмы. Оценены вероятные геотектонические условия возникновения ультракалиевых кислых магм.
\end{abstract}

Ключевые слова: щелочно-базитовая магма; известково-щелочной лампрофир; гранитоидные ксенолиты; контактовое плавление; ультракалиевый кислый расплав; петрогенетические и тектонические условия; Гусиноозерская дайка; Забайкалье

\section{1. ВВЕДЕНИЕ}

Для обоснования петрогенетических моделей формирования гранитоидных расплавов, особенно в крупных объемах, во внутриплитных условиях предполагается участие горячих мафических (мантийных) магм, которые внедряются в кору и вызывают ее плавление [Huppert, Sparks, 1988; Litvinovsky et al., 1993; Yarmolyuk et al., 1997; Tsygankov et al., 2016; и дp.]. Геолого-петрологические доказательства подобной модели базируются на свидетельствах пространственно-временной ассоциации кислых и основных магматических пород и изотопногеохимических признаках участия мантийного вещества в формировании некоторых гранитоидов [Yarmolyuk, Kovalenko, 1991; Jahn et al., 2009; Litvinovsky et al., 2011]. Использование изотопно-геохимического подхода предопределено тем, что в большинстве случаев гранитоиды кристаллизовались из магм, удаленных на значительное расстояние от места их выплавления.
Прямые свидетельства модели плавления коровых пород в контакте с мафическими магмами могут наблюдаться в некоторых ксенолитах и экзоконтактах базитовых субвулканитов [Ramakrishnan, Bhattacharyya, 1985; Zanvilevich et al., 1988; Philpotts, Asher, 1993; Zanvilevich, Litvinovsky, 1996; Hersum et al., 2007; и $\partial p$.], поэтому изучение подобных субвулканических систем важно для раскрытия процессов гранитообразования при воздействии мантийных магм на вещество коры.

Следующим аспектом необходимости их исследования является то, что продукты контактового плавления могут быть существенно обогащены калием относительно протолитового субстрата. В этом случае они являются ключом к расшифровке природы ультракалиевых кислых расплавов, с которыми нередко связана редкометалльная минерализация [Antipin et al., 2002; Vladimirov et al., 2007].

В настоящей статье на примере изучения гранитоидных ксенолитов в щелочно-мафической (лампрофировой) Гусиноозерской дайке (Западное За- 

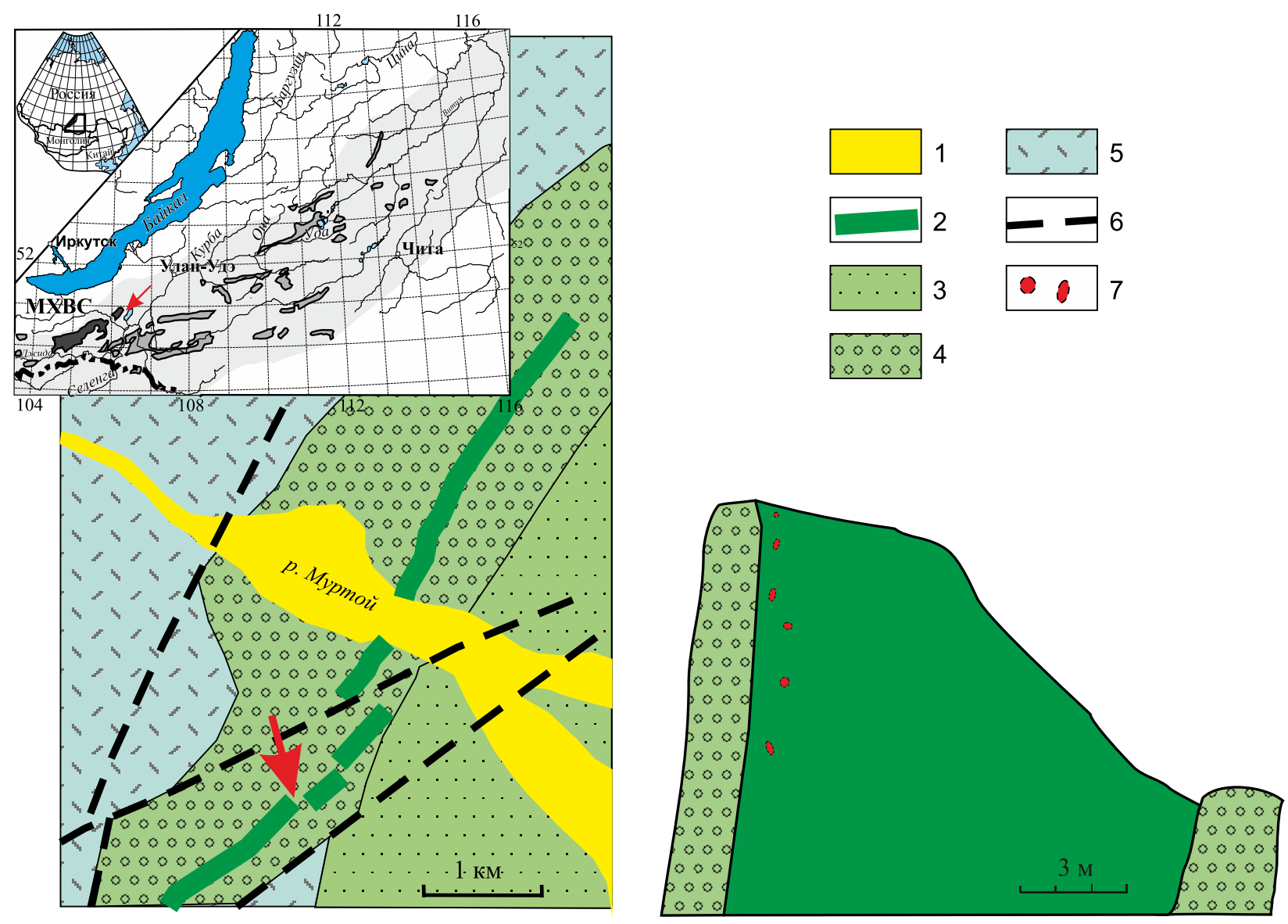

Рис. 1. Геологическое строение низовья пади Муртой, юго-западный борт Гусиноозерской впадины.

1 - кайнозойские отложения; 2 - лампрофировая (щелочно-мафическая) Гусиноозерская дайка; 3-4 - меловая гусиноозерская серия: 3 - песчаники, 4 - конгломераты; 5 - юрско-меловые трахибазальтовые вулканиты; 6 - разломные нарушения; 7 - гранитоидные ксенолиты Гусиноозерской дайки. Врезка в верхнем левом углу: границы мезозойской рифтовой зоны (выделена светло-серым цветом) и распространение позднеюрско-меловых вулканитов (серым) по [Yarmolyuk et al., 1998]. Стрелкой показано положение Гусиноозерской дайки, МХВС - Малохамардабанская вулканотектоническая структура (выделена темно-серым цветом). В нижнем правом углу: схематическая зарисовка обнажения Гусиноозерской дайки с заключенными в ней гранитоидными ксенолитами. Положение обнажения на схеме геологического строения указано стрелкой.

Fig. 1. Geological structure of the lower reaches of the Murtoi deep at the southwestern side of the Gusinoozerskaya depression.

1 - Cenozoic deposits; 2 - lamprophyric (alkaline mafic) Gusinoozerskaya dyke; 3-4 - Cretaceous Gusinoozerskaya series: 3 - sandstones, 4 - conglomerates; 5 - Jurassic-Cretaceous trachybasalt volcanic rocks; 6 - faults; 7 - granitoid xenoliths of the Gusinoozerskaya dyke. In the upper left inset, the boundaries of the Mesozoic rift zone (light grey) and the Jurassic-Cretaceous volcanic rocks (grey) are shown after [Yarmolyuk et al., 1998]. The arrow shows the position of the Gusinoozerskaya dyke, MXBC - Malokhamardaban volcano-tectonic structure (dark grey). The lower right inset shows a sketch of an outcrop in the Gusinoozerskaya dyke with granitoid xenoliths. In the scheme of the geological structure, this outcrop is marked by the arrow.

байкалье) показано, что они испытали частичное плавление в контакте с вмещающей базитовой магмой, производные плавления имеют высоко- и ультракалиевый состав, а также приведены данные об условиях плавления.

\section{2. ГЕОЛОГИЧЕСКОЕ СТРОЕНИЕ ГУСИНООЗЕРСКОЙ ДАЙКИ}

Гусиноозерская дайка, известная также как Муртойская, располагается в центральной части
Западного Забайкалья в северо-западном борту Гусиноозерской впадины, в низовье пади Муртой (рис. 1).

Дайка отчетливо выделяется в рельефе в виде гребня высотой до 20 м, ее протяженность составляет около 8 км при мощности, варьирующейся от 1 до 15 м. Она имеет северо-восточное простирание $\left(35-40^{\circ}\right)$, разбита серией тектонических нарушений на несколько блоков. В северо-восточной части дайка разветвляется на серию тонких субпараллельных выклинивающихся апофиз. Дайка 
залегает субвертикально с падением на юго-восток под углом 80-85․ Она прорывает меловые отложения гусиноозерской серии. Непосредственно в месте ее выхода на поверхность она сечет конгломераты, галька которых представлена трахибазальтами. Визуально породы, слагающие крупнообломочный осадочный материал, идентичны юрскомеловым вулканитам Хамбинского хребта, обрамляющим Гусиноозерскую впадину с северо-западной стороны. Вокруг дайки отчетливо проявлены экзоконтактовые изменения вмещающих конгломератов, которые выражаются в изменении степени цементации. На удалении от дайки вмещающие отложения слабо сцементированы и имеют серую и светло-серую окраску. При приближении к дайке они приобретают красноватый цвет, который постепенно изменяется до бордового. В 1.5-2.0-метровом экзоконтакте вмещающие конгломераты представляют собой плотную крепкую породу темно-серого, черного цвета, претерпевшую контактовую перекристаллизацию цемента.

Дайка имеет раннемеловой (117-122 млн лет) возраст, оцененный $\mathrm{K}-\mathrm{Ar}$ и $\mathrm{Rb}-\mathrm{Sr}$ изотопными методами датирования [Litvinovsky et al., 1989]. Она, наряду с покровами щелочных базальтов и проявлениями тефрит-фонолитовых вулканитов [Ivanov, Yarmolyuk, 1996], сформировалась в конце раннемелового этапа развития крупнейшей юрско-меловой вулканотектонической структуры Западного Забайкалья, занимающей Малохамардабанский и Хамбинский хребты (рис. 1, врезка) [Vorontsov et al., 2002; Khubanov et al., 2015].

Предшественниками породы дайки классифицировались как сиенит-диориты [Rozinov, 1967], как эссекситы [Litvinovsky et al., 1989; Andryushchenko et al., 2010] или камптониты [Shadaev, 2001]. Термин «эссекситы» в полной мере отражает щелочно-базитовый состав (с нормативным нефелином) этих пород, образовавшихся в гипабиссальных условиях. Однако с учетом того, что породы дайки имеют порфировую структуру и вкрапленники представлены исключительно цветными минералами, а полевошпатовые фенокристаллы и фельдшпатоиды отсутствуют, согласно [Rock, 1984], данные породы являются шошонитовыми (известково-щелочными) или полевошпатовыми лампрофирами [Petrographic Code..., 2009].

В формировании дайки выделено две основные фазы становления. В первую фазу внедрились серые лампрофиры с мелко- и среднезернистой основной массой, занимающие центральную и северо-восточную часть дайки. Лампрофиры этой фазы отличаются текстурным разнообразием - это массивные, полосчатые и глобулярные разновидности, в которых присутствуют различные включения иных пород. В эндоконтакте породы мелкозерни- стые. Вторая фаза внедрения представлена черными тонкозернистыми лампрофирами, они прорывают первую фазу в виде жил мощностью до 70 см и полностью слагают юго-западное окончание Гусиноозерской дайки. Внешне это плотные тонкозернистые породы, похожие на афанитовые базальты, но местами в них просматриваются вкрапленники биотита. Предшественниками также выделялась промежуточная стадия внедрения, в течение которой произошло становление лампрофировых пород голубовато-серого цвета с отчетливой порфировой структурой и мелкозернистой основной массой. Однако наши наблюдения показали, что эти породы имеют подчиненное значение, распространены локально в центральной части дайки и не обнаруживают секущих соотношений с окружающими лампрофирами. Они являются разновидностью лампрофиров первой фазы.

Для пород первой фазы характерны разнообразные включения. По составу они подразделяются на мафические и салические (гранитоидные), по генезису - на генетически взаимосвязанные с вмещающими лампрофирами и ксенолиты. Мафические включения, генетически взаимосвязанные с лампрофирами, - это округлые, овальные, вытянутые, закрученные в спираль обособления более тонкозернистых разновидностей в среднезернистых лампрофирах. Форма этих включений свидетельствует о их деформации в пластичном состоянии, что очень напоминает структуры минглинга, т.е. механического смешения разноплотностных и разновязких жидкостей. Мафические ксенолиты представлены обломками порфировых вулканитов с вкрапленниками плагиоклаза, внешне похожих на галечный материал вмещающей осадочной толщи и пространственно ассоциирующих юрских трахибазальтов.

Салические образования, родственные вмещающим лампрофирам, представленные редкими мелко-, среднезернистыми сиенитовыми шлирами и прожилками, описаны в работе М.Г. Шадаева [Shadaev, 2001]. Шлиры имеют нечеткие границы с вмещающим лампрофиром, а прожилки занимают поперечное и продольное положение по отношению к простиранию дайки, что предполагает их связь с контракционными трещинами. Подобная морфология обособлений и прожилков, данные о их минералогическом и геохимическом составе, согласно М.Г. Шадаеву, свидетельствуют о том, что они образовались при сегрегации порций остаточного сиенитового расплава, дифференциатов лампрофировой магмы.

Гранитоидные ксенолиты, представляющие основной предмет исследований, - это округлые и, реже, угловатые единичные образования массивных и полосчатых пород с резкой границей с 
вмещающими лампрофирами. Они распространены в приконтактовой зоне первой фазы в юго-западной части Гусиноозерской дайки со стороны висячего крыла (рис. 1). Плотность распространения невелика - единичные ксенолиты на два квадратных метра площади дайки. Достаточно много ксенолитов обнаруживается в глыбах среди коллювия в подножии дайки. Скорее всего, гранитоидные ксенолиты захвачены щелочно-мафической магмой дайки из фундамента Гусиноозерской впадины.

Поперечный размер ксенолитов варьируется от 3-5 до 15-20 см. Визуально это серые породы преимущественно кварц-полевошпатового состава, практически лишенные темноцветных минералов, но с варьирующимся количеством пустот, возможно, образованных за счет выщелачивания темноцветов. В области контакта с вмещающим лампрофиром вокруг гранитоидного включения может наблюдаться реакционная кайма серого цвета шириной в первые миллиметры (рис. 2, $A$, врезка). Как будет показано ниже, по внешнему облику, внутренней морфологии и составу данные включения представляют собой ксенолиты гранитоидов, вынесенные из кристаллического фундамента магмой дайки, хотя ранее М.И. Розиновым [Rozinov, 1967] они трактовались как дифференциаты щелочнобазитовой магмы.

\section{3. АНАЛИТИЧЕСКИЕ МЕТОДЫ}

Общий анализ пород был выполнен в Геологическом институте СО РАН (г. Улан-Удэ). Содержания $\mathrm{SiO}_{2}, \mathrm{TiO}_{2}, \mathrm{Al}_{2} \mathrm{O}_{3}, \mathrm{P}_{2} \mathrm{O}_{5}$ определяли фотометрическим методом; $\mathrm{CaO}, \mathrm{MgO}, \mathrm{MnO}, \mathrm{Fe}_{2} \mathrm{O}_{3}$ - атомноабсорбционным; $\mathrm{FeO}$ - титриметрическим; $\mathrm{Na}_{2} \mathrm{O}$, $\mathrm{K}_{2} \mathrm{O}$ - методом фотометрии пламени (аналитики А.А. Цыренова, В.А. Иванова, Г.И. Булдаева, И.В. Бардамова). Концентрации элементов-примесей (Rb, $\mathrm{Sr}, \mathrm{Zr}, \mathrm{Ba}, \mathrm{Nb}$,) определены методом рентгеноспектрального анализа на установке VRA-30 (аналитик Б.Ж. Жалсараев).

Исследование внутренней структуры и состава ксенолитов и производных их плавления проводилось в ГИН СО РАН на полированных шлифах с помощью сканирующего электронного микроскопа LEO-1430 VP (LEO Electron Microscopy Ltd) с энергодисперсионным спектрометром INCAEnergy-300 (Oxford Instruments Analytical Ltd) при ускоряющем напряжении 20 кВ, электронном токе <0.5 нА, размере зонда 0.1 мкм. Несмотря на малый размер зонда, локальность метода при данном ускоряющем напряжении в силикатных минералах составляет 3-5 мкм, что обусловлено рассеянием электронов в материале образца. Для снижения влия-
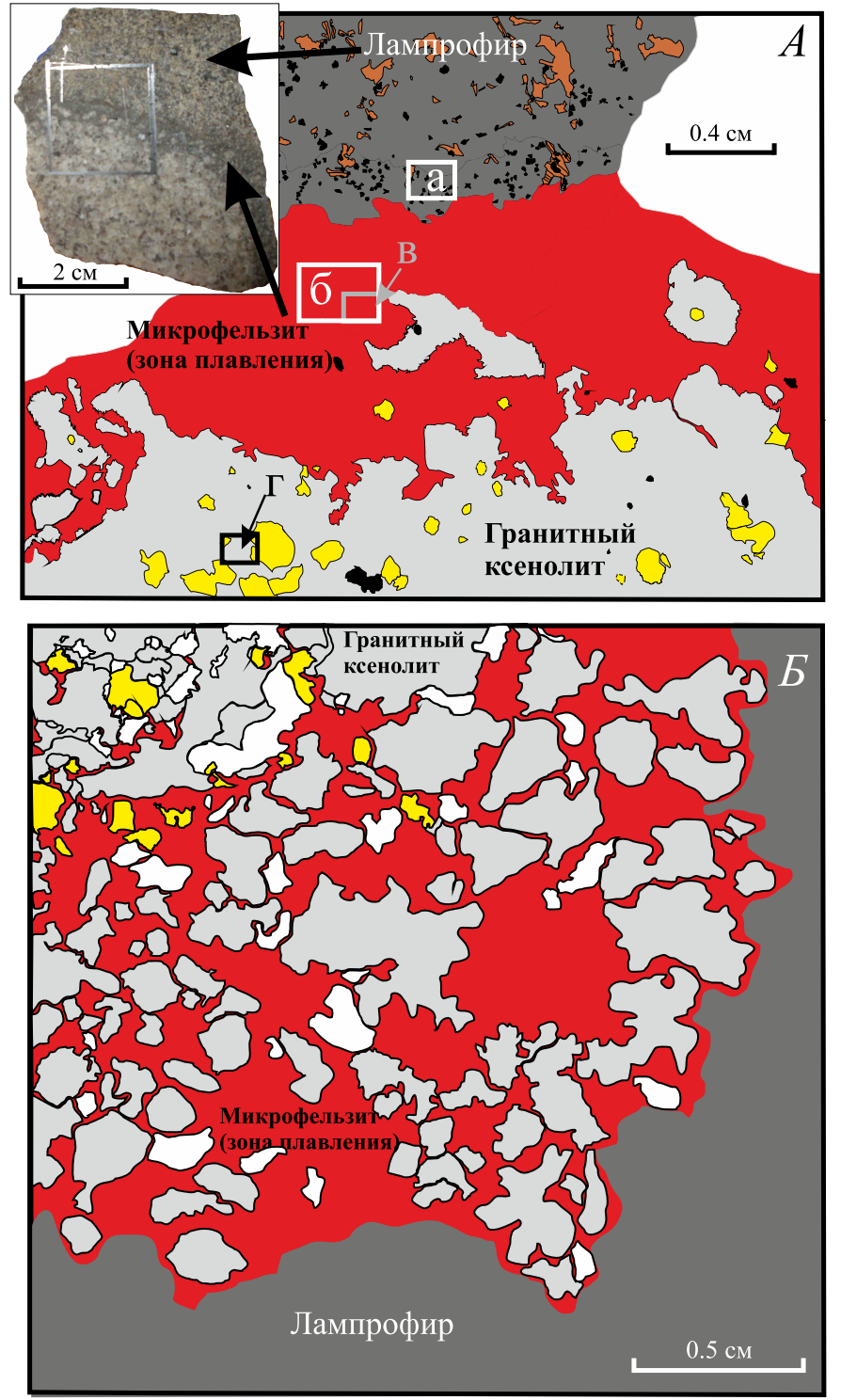

Рис. 2. Схематические зарисовки шлифов контакта гранитных ксенолитов и вмещающих лампрофиров.

$A$ - шлиф образца Р40: темно-серым показано поле лампрофира, в котором выделены кристаллы биотита (коричневым) и рудных минералов (оксидов) (черным); светлосерым обрисована полевошпатовая составляющая гранитного ксенолита; желтым - зерна кварца ксенолита; красным выделены микрофельзитовый агрегат, стекло. В левом верхнем углу - макрофотография образца Р40. Прямоугольниками показано положение участков, изображенных на BSEфотографиях $(a-2)$ рисунка 3. Б - шлиф образца GP4-10b: темно-серый - лампрофир; светло-серый - полевые шпаты и желтый - зерна кварца гранитного ксенолита; красный микрофельзитовый агрегат.

Fig. 2. Sketches of microsections showing contacts between granite xenoliths and host lamprophyres.

$A$ - P40 specimen microsection: dark grey - lamprophyre, brown - biotite crystals, black - ore minerals (oxides); light grey - feldspar in granite xenolith; yellow - xenolite quartz grains; red - microfelsite aggregate, glass. Upper left insert - macro image of P40 specimen. Boxes - locations shown in BSE images $(a-2)$ in Fig. 3. 5 - microsection of GP4-10b specimen: dark grey - lamprophyre, light grey - feldspar, yellow - xenolith quartz grains, red - microfelsite aggregate. 
ния микрорельефа образца на точность анализа часть анализов минералов выполнялась на небольших участках шлифа в режиме растра. В этом же режиме выполнялись анализы для получения среднего состава структур распада (замещения) полевых шпатов и для оценки состава микроучастков породы. Пределы обнаружения составляют 0.n мас. \%, ошибка анализа на сумму - 2-4 мас. \%.

$\mathrm{U}-\mathrm{Pb}$ датирование цирконов из гранитного ксенолита проводилось с помощью лазерной абляции и масс-спектрометрии с индуктивно-связанной плазмой (LA-ICP-MS). Определение возраста выполнено согласно методике [Khubanov et al., 2016; Buyantuev et al., 2017], при этом испарение цирконов лазерным лучом осуществлялось с поверхности петрографического шлифа, наклеенного на предметное стекло эпоксидной смолой.

Изотопный состав кислорода определялся на газовом масс-спектрометре Finnigan MAT 253, для экстракции кислорода в среде BrF5 использовалась установка лазерной абляции MIR 10-30 ( $\left.\mathrm{CO}_{2}\right)$ по методике [Sharp, 1990]. В качестве внешних стандартов и контрольных образцов использовались международные и внутрилабораторные эталоны кварца NBS-28, GI-1, биотита NBS-30, граната UWG-2. Погрешность определения $\delta 180$ на уровне $1 \sigma$ составляла не более $\pm 0.2 \%$.

\section{4. КРАТКАЯ ВЕЩЕСТВЕННАЯ ХАРАКТЕРИСТИКА ПОРОД ДАЙКИ}

\section{1. ПЕТРОГРАФИЯ}

Породы первой и второй фазы становления дайки близки по минеральному составу вкрапленников и основной массы. Фенокристаллы, представленные биотитом, клинопироксеном, апатитом, реже амфиболом, составляют от долей процента до 10 \% объема породы. Основная масса - это преимущественно андезин (28-33 мол. \% An), тройной полевой шпат $\left(\mathrm{Or}_{10-12}, \mathrm{Ab}_{70-75}, \mathrm{An}_{13-15}\right)$, щелочной полевой шпат (45-50 мол. \% Ort), занимающие около 50-60 \% базиса, биотит, рудные минералы (5-7 \%), апатит (3-5 \%). При этом в апатите отмечается до $3 \%$ фтора, что приближает его к фтор-апатитам, а также до 2.5 \% серы и до 0.5 \% хлора. Характерно присутствие в породах дайки интерстиционного карбоната и цеолитов, заполняющих межзерновое пространство. Обращает на себя внимание тот факт, что в составе лампрофира вблизи контакта с ксенолитом присутствует кварц (рис. 3, a), хотя в целом порода дайки имеет нефелин-нормативный состав. Аллотриоморфные очертания кварца в лампрофире вблизи контакта с гранитоидными ксенолитами предполагают, что его образование про- изошло на заключительных стадиях кристаллизации щелочно-базитовой магмы.

Сиенитовые шлиры и прожилки более чем на 80 \% сложены полевошпатовым агрегатом (тройной полевой шпат, альбит и калий-натровый полевой шпат) и подчиненным количеством щелочного клинопироксена и биотита, кроме того в них отмечается таблитчатый стильбит в количестве до $10 \%$.

Среди гранитоидных ксенолитов доминируют породы щелочно-полевошпат-гранитного состава: щелочной полевой шпат (Or $\left.33-51, \mathrm{Ab}_{48-61}, \mathrm{An}_{0-11}\right)$ 70-75 \%, кварц - 25-30 \%, плагиоклаз - единичные зерна, рудный минерал - менее 1 \%. Реже встречаются ксенолиты сиенитов и плагиогранитов. В плагиограните (образец GP14-10) плагиоклаз представлен андезином (Or $\left.7-13, \mathrm{Ab}_{48-58}, \mathrm{An}_{34-43}\right)$ (табл. 1). По размеру слагающих минералов породы ксенолитов варьируются от мелкозернистых до крупнозернистых разностей. Темноцветные минералы практически не наблюдаются, на их месте обнаруживаются каверны; исключение составляют сиенитовые ксенолиты, в которых выявлен пироксен. Полевые шпаты лишены пертитовых структур. В них и в кварце широко развита микротрещиноватость, возможно, отражающая термическое воздействие. Среди акцессорных выделяются рудный минерал, циркон, апатит.

\section{2. ПЕТРОХИмИЯ}

По химическому составу лампрофиры первой и второй фазы становления дайки близки друг другу - это щелочные базитовые породы $\left(\mathrm{Na}_{2} \mathrm{O}+\mathrm{K}_{2} \mathrm{O}\right.$ 8-11 мас. \% при $\mathrm{SiO}_{2}$ 50-52 мас. \%) (табл. 2). На классификационной диаграмме TAS лампрофиры ложатся в компактную область между фонотефритами и тефрифонолитами. Практически повсеместно данные породы характеризуются нефелиннормативным составом (ne до $10 \%$ ), $\mathrm{K}_{2} \mathrm{O} / \mathrm{Na}_{2} \mathrm{O}$ варьируется от 0.7 до 0.9 , при содержании $\mathrm{K}_{2} \mathrm{O}$ 2 3.5-5.0 мас. \%, концентрация $\mathrm{Sr}$ составляет $2300-$ 2500 pрm и Ва - до 3000 ppm, что типично для шошонитовых (известково-щелочных) лампрофиров [Rock, 1984].

Сиенитовые шлиры и прожилки характеризуются содержанием $\mathrm{SiO}_{2}$ 62-64 мас. \% и суммой щелочей 10-13 мас. \% (табл. 2). Они имеют концентрацию $\mathrm{Sr}$ (до 2600 ppm), близкую к лампрофирам, пониженные содержания Ва (300-2000 ppm) и повышенные $\mathrm{Zr}$ (1000-1600 ppm) относительно лампрофиров (с Zr 500 ppm) (табл. 2).

Для гранитоидных ксенолитов имеется только валовый состав щелочно-полевошпатовых гранитов (образцы Р40 и Р40A) (табл. 2): $\mathrm{SiO}_{2} \sim 74$ мас. \%, $\mathrm{Na}_{2} \mathrm{O}+\mathrm{K}_{2} \mathrm{O} \sim 10$ мас. \%, агпаитность Ка 0.9. Обраща- 

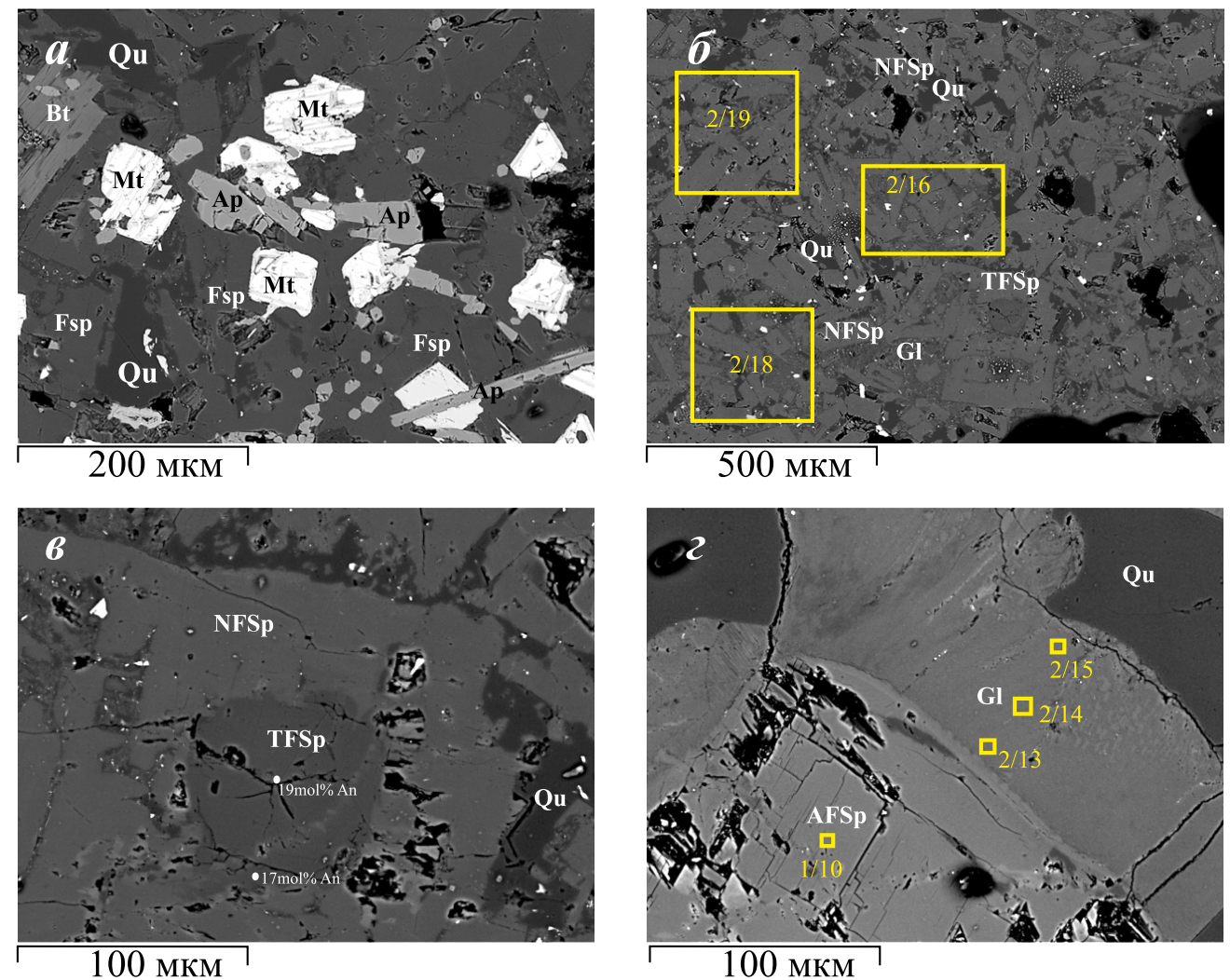

Рис. 3. Цифровые изображения шлифов, полученных с помощью растрового электронного микроскопа в режиме обратно-рассеянных электронов (BSE).

Образец щелочно-полевошпатового гранита Р40, положение участков в шлифе показано на рисунке $2, A: a-$ лампрофир вблизи контакта с гранитным ксенолитом; б - микрофельзит (зона плавления) в периферии ксенолита с микрогипидиоморфнозернистой и микроортофировой структурой; в - зерно тройного полевого шпата в щелочно-полевошпатовой рубашке в микрофельзитовой зоне (см. рис. 2, A), с содержаниями анортитовой молекулы (\% mol An) в выделенных точках; 2 - стекло на контакте кварца и щелочного полевого шпата ксенолита. Буквенные обозначения: Bt - биотит, Ap - апатит, FSp - полевой шпат, AFSp щелочной полевой шпат ксенолита, NFSp - новообразованный полевой шпат, TFSp - тройной полевой шпат, Pl - плагиоклаз, Qu - кварц, Gl - стекло. Квадратами выделены примеры зон растрового анализа электронным сканирующим микроскопом, цифрами указаны столбцы с данными элементного состава в таблице 1.

Fig. 3. Digital images of microsections obtained using a scanning electron microscope in the BSE mode.

P40 specimen of alkaline feldspar granite. The locations in the microsection are shown in Fig. 2 A: $a$ - lamprophyre near the contact with granite xenolith; $\sigma$ - microfelsite (melting zone) in the periphery of the xenolith with microhypidiomorphic granular and microorthophyric structure; 8 - grain of ternary feldspar in the alkaline feldspar cover in the microfelsite zone (see Fig. 2, $A$ ), and the contents of anorthite molecule (\% mol An) in the selected points; 2 - glass at the contact between quartz and alkaline feldspar xenolith. Bt - biotite, Ap - apatite, FSp - feldspar, AFSp - alkaline feldspar of xenolith, NFSp - young feldspar, TFSp - ternary feldspar, Pl - plagioclase, Qu quartz, Gl - glass. Boxes - examples of the zones of raster analysis with an electronic scanning microscope. Numbers indicate the columns with elemental composition data in Table 1.

ет на себя внимание то, что в валовом составе щелочно-полевошпат-гранитных ксенолитов содержание $\mathrm{K}_{2} \mathrm{O}$ преобладает над $\mathrm{Na}_{2} \mathrm{O}$ в два раза, тогда как в первичном полевом шпате, практически единственном щелочесодержащем минерале, это соотношение близко к единице (см. табл. 1). Вероятно, такое несоответствие обусловлено высокой долей производных плавления (микрофельзита и стекла), обогащенных калием, в составе навесок из ксенолитов при общем химическом анализе. Данные по валовому химическому составу сиенитовых и плагиогранитных ксенолитов отсутствуют.

\section{5. ОСОБЕННОСТИ СТРУКТУРЫ И СОСТАВА ПРОИЗВОДНЫХ ПЛАВЛЕНИЯ ГРАНИТОИДНЫХ КСЕНОЛИТОВ}

Гранитные ксенолиты часто обнаруживают в себе реакционную кайму серого цвета шириной в первые миллиметры непосредственно в зоне контакта с лампрофиром (см. рис. 2, $A$, врезка). Данная кайма не выдержана по мощности (до первых миллиметров) и сложена только тонкозернистым материалом микрофельзитового и/или криптокристаллического сложения, без вкрапленников и/или первичных (ксенолитных) зерен и их агрегатов. 
V.B. Khubanov et al.: Melting conditions of granitoid xenoliths in contact with alkaline mafic magma...

Т а б л и ц а 1. Представительные химические анализы полевых шпатов из гранитных ксенолитов Гусиноозерской дайки

$\mathrm{T}$ a b l e 1. Representative chemical analysis of feldspars from granite xenoliths, Gusinoozerskaya dyke

\begin{tabular}{|c|c|c|c|c|c|c|c|c|c|c|c|c|}
\hline Номер & 1 & 2 & 3 & 4 & 5 & $\begin{array}{l}\text { Cp. сост., } \\
n=15\end{array}$ & 6 & 7 & 8 & 9 & 10 & $\begin{array}{l}\text { Ср. сост., } \\
n=21\end{array}$ \\
\hline Образец & \multicolumn{6}{|c|}{ GP14-10 } & \multicolumn{3}{|l|}{$\mathrm{P} 40 \mathrm{~A}$} & \multicolumn{3}{|l|}{$\mathrm{P} 40$} \\
\hline Минерал & \multicolumn{6}{|c|}{ Плагиоклаз } & \multicolumn{6}{|c|}{ Щелочной полевой шпат } \\
\hline $\mathrm{SiO}_{2}$ & 62.88 & 62.66 & 63.37 & 61.85 & 63.03 & 62.33 & 66.45 & 65.23 & 65.02 & 66.01 & 67.22 & 66.24 \\
\hline $\mathrm{Al}_{2} \mathrm{O}_{3}$ & 23.01 & 22.20 & 22.79 & 22.73 & 22.62 & 22.34 & 18.57 & 19.61 & 18.88 & 19.33 & 19.56 & 19.44 \\
\hline $\mathrm{FeO}$ & - & - & - & 0.44 & - & 0.05 & 0.71 & 0.32 & - & - & - & 0.28 \\
\hline $\mathrm{CaO}$ & 4.52 & 4.23 & 4.86 & 4.81 & 4.91 & 4.75 & - & 0.95 & 0.98 & 0.97 & 1.02 & 0.88 \\
\hline $\mathrm{Na}_{2} \mathrm{O}$ & 7.29 & 7.18 & 7.17 & 6.69 & 7.32 & 7.27 & 5.84 & 6.35 & 6.17 & 7.00 & 6.29 & 6.41 \\
\hline $\mathrm{K}_{2} \mathrm{O}$ & 2.49 & 2.04 & 2.05 & 2.32 & 1.81 & 1.92 & 8.96 & 6.72 & 7.08 & 6.75 & 7.78 & 7.31 \\
\hline Сумма & 100.19 & 98.31 & 100.24 & 98.84 & 99.69 & 98.66 & 100.53 & 99.18 & 98.13 & 100.06 & 101.87 & 100.57 \\
\hline $\mathrm{K}_{2} \mathrm{O} / \mathrm{Na}_{2} \mathrm{O}$ & 0.34 & 0.28 & 0.29 & 0.35 & 0.25 & 0.27 & 1.53 & 1.06 & 1.15 & 0.96 & 1.24 & 1.16 \\
\hline $\mathrm{Ab}$ & 0.52 & 0.54 & 0.51 & 0.49 & 0.52 & 0.53 & 0.50 & 0.54 & 0.52 & 0.56 & 0.50 & 0.53 \\
\hline An & 0.36 & 0.36 & 0.39 & 0.39 & 0.39 & 0.38 & - & 0.09 & 0.09 & 0.08 & 0.09 & 0.07 \\
\hline Ort & 0.12 & 0.10 & 0.10 & 0.11 & 0.09 & 0.09 & 0.50 & 0.37 & 0.39 & 0.36 & 0.41 & 0.40 \\
\hline
\end{tabular}

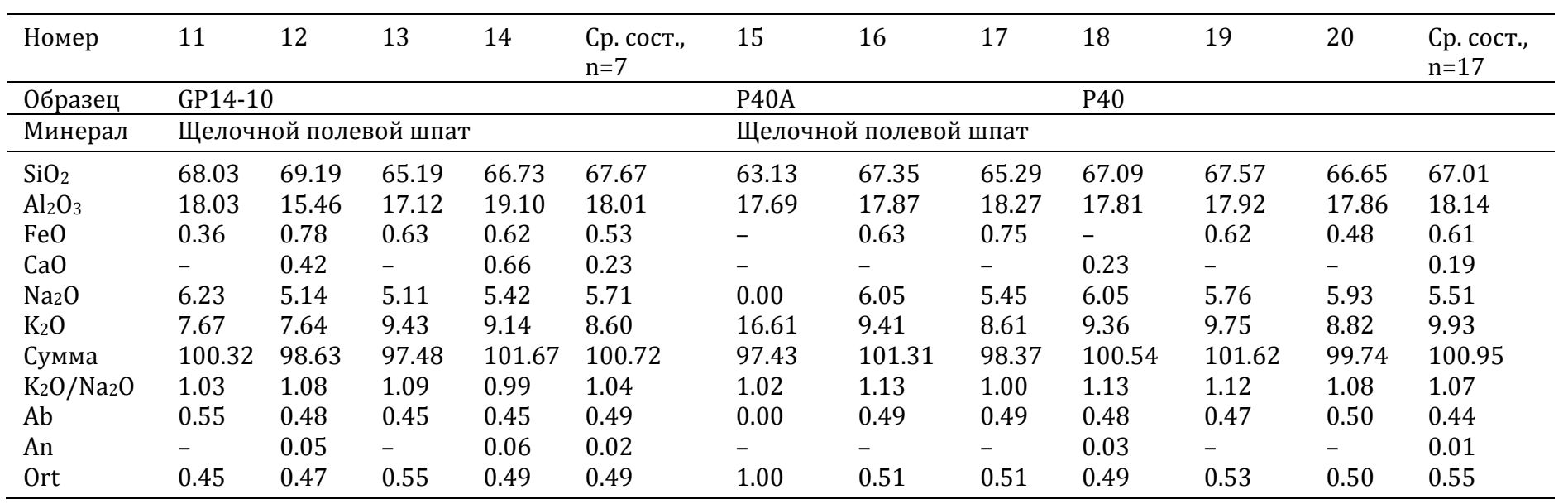

П р и м е ч а н и е. 1-10 - составы первичных полевых шпатов гранитных ксенолитов: плагиогранитовых (1-5) и щелочнополевошпатовых (6-10); 11-20 - составы новообразованных полевых шпатов, кристаллизованных из производных частичного контактового плавления гранитных ксенолитов: из плагиогранита (11-14) и из щелочно-полевошпатового гранита (15-20). Ср. сост. - средний состав, $\mathrm{n}$ - количество усредненных анализов, прочерк - ниже пределов обнаружения.

$\mathrm{N}$ o t e. 1-10 - compositions of primary feldspars from granite xenoliths: 1-5 - plagiogranite, 6-10 - alkaline feldspar. 11-20 - compositions of young feldspars crystallized from the products of partial contact melting of granite xenoliths: 11-14 - from plagiogranite, 15-20 from alkaline-feldspar granite. Ср. сост. - average composition, $\mathrm{n}$ - number of averaged assays, dash - below detection limits.

Этот материал мы условно назвали «микрофельзитом». Нередко среди микрофельзита имеются участки, сложенные карбонатным веществом. На высокоразрешающих снимках в лучах обратно-рассеянных электронов (BSE) (рис. 3, б) микрофельзит представляет собой агрегат с микрогипидиоморфно-зернистой и микроортофировой структурой, с идиоморфными микролитами щелочного полевого шпата, ксеноморфным кварцем и стеклом в интерстициях.

С удалением от контакта с лампрофиром в ксенолите появляются относительно крупные кристаллы и/или их фрагменты и агрегаты полевого шпата и кварца, которые разобщены и, вместе с тонкозернистым микрофельзитовым цементом, образуют зону с гломерогранулярной структурой. Наиболее ярко данная структура выражена в шлифе GP-4-10b (cм. рис. 2, Б) и характеризуется тем, что в ней отдельные зерна и агрегаты зерен имеют плавно-извилистые очертания, причем часто линии контуров соседних агрегатов кварца и полевого шпата субпараллельны друг другу. Такая структура типична для кварц-полевошпатовых пород, испытавших частичное плавление [Haweks, 1929; Polovinkina, 1966].

Здесь же встречаются редкие зональные зерна тройного полевого шпата (Or 8 -15, $\left.\mathrm{Ab}_{66-75}, \mathrm{An}_{8-15}\right)$ (рис. 3, б, в; рис. 4). Центральная часть зональных 
Т а б л и ц а 2. Представительные общие химические анализы пород Гусиноозерской дайки

$\mathrm{T}$ a b l e 2. Representative general chemical analysis of the rocks sampled from the Gusinoozerskaya dyke

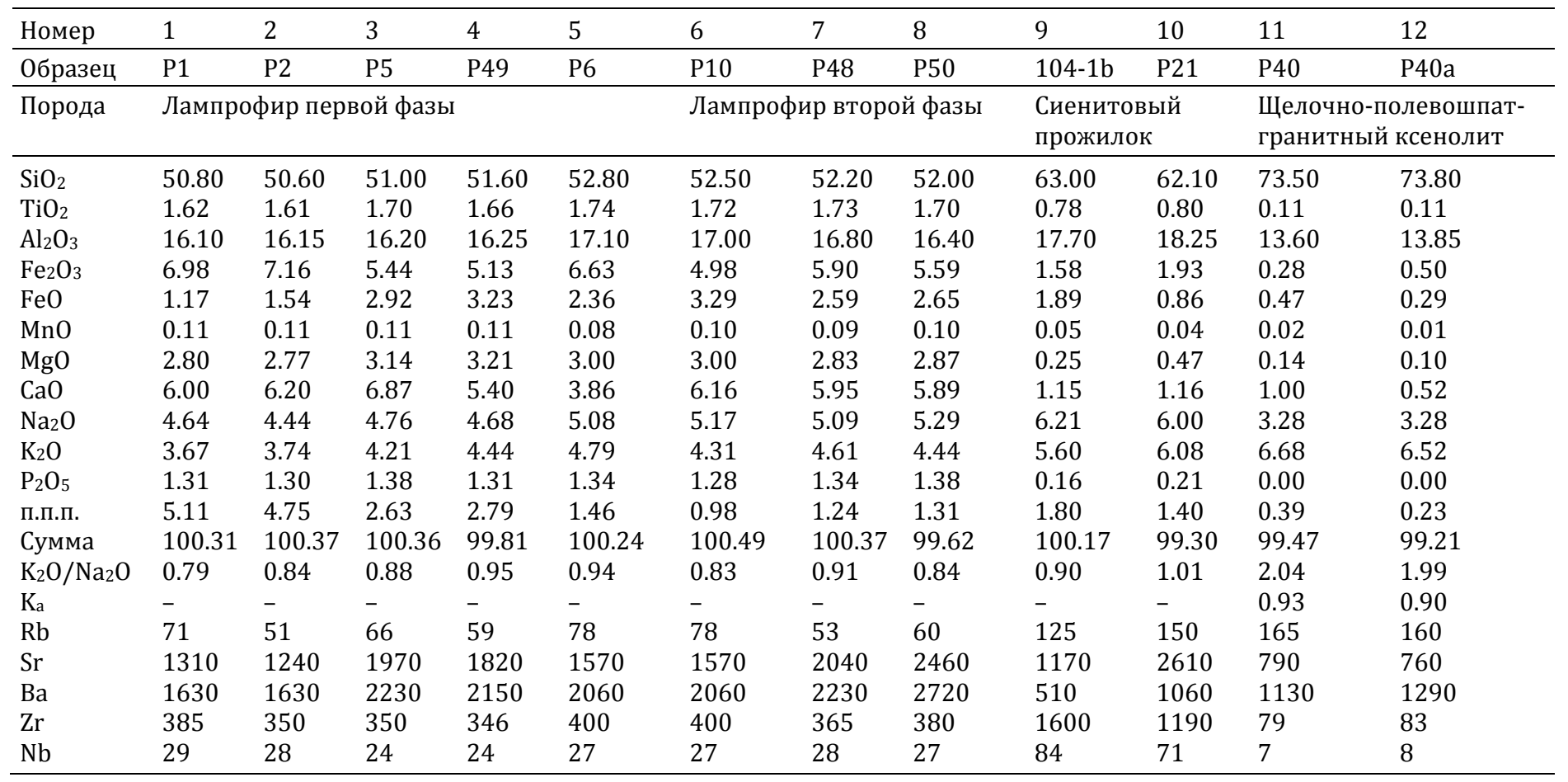

П р и м е ч а н и е. П.п.п. - потери при прокаливании, прочерк - не определялось, $\mathrm{K}_{\mathrm{a}}=\left(\mathrm{K}_{2} \mathrm{O}+\mathrm{Na}_{2} \mathrm{O}\right) / \mathrm{Al}_{2} \mathrm{O}_{3}$ в молекулярных количествах, анализ № 9 заимствован из [Shadaev, 2001].

$\mathrm{N}$ o t е. П.п.п. - LOI (loss on ignition); dash - not determined; $\mathrm{K}_{\mathrm{a}}=\left(\mathrm{K}_{2} \mathrm{O}+\mathrm{Na}_{2} \mathrm{O}\right) / \mathrm{Al}_{2} \mathrm{O}_{3}$ in molecular quantities; assay 9 from [Shadaev, 2001].

$a$

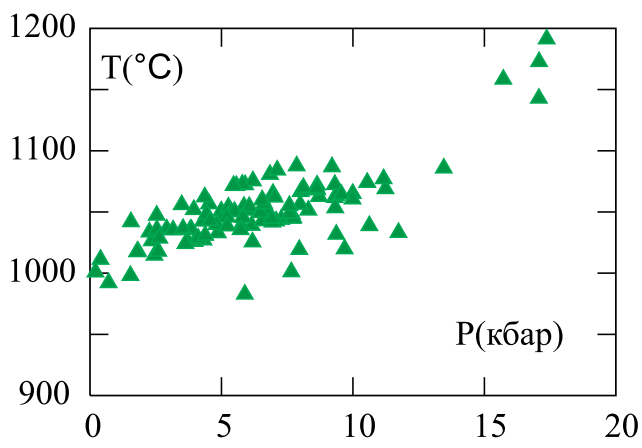

$\sigma$

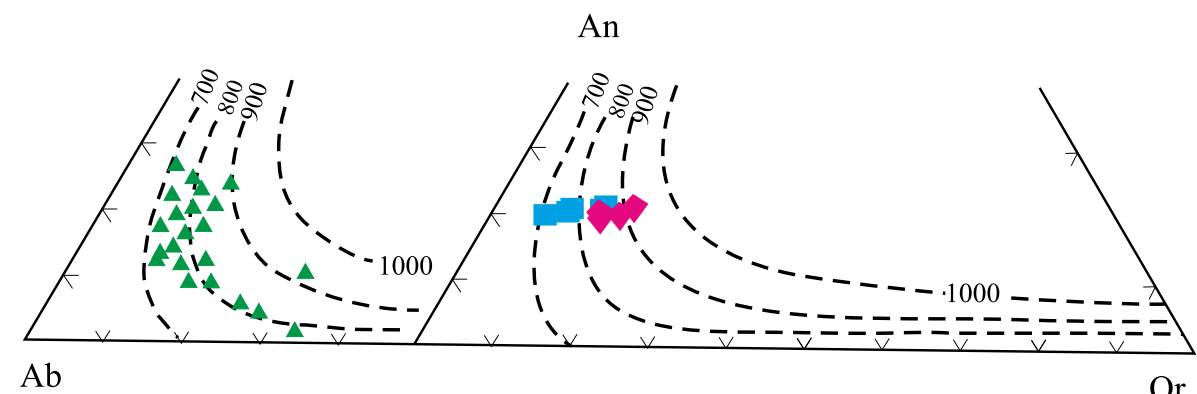

Рис. 4. Оценка Р-Т параметров кристаллизации минералов.

$a$ - график температуры и давления кристаллизации клинопироксеновых фенокристаллов и субфенокристаллов из лампрофиров Гусиноозерской дайки, рассчитанных по [Putirka et al., 2003]; б - положение фигуративных точек тройных полевых шпатов лампрофиров на диаграмме Ab-An-Ort; в - положение фигуративных точек тройных полевых шпатов из зоны плавления гранитного ксенолита на диаграмме Ab-An-Ort. Изотермы на диаграмме Ab-An-Ort для P=5 кбар по [Nekvasil, 1992]. 3десь и далее полные таблицы с аналитическими данными доступны по запросу к В.Б. Хубанову (khubanov@mail.ru).

Fig. 4. Estimation of P-T parameters of minerals crystallization.

$a$ - graph of the temperature and pressure of crystallization of clinopyroxene phenocrysts and sub-phenocrysts from lamprophyres of the Gusinoozerskaya dyke calculated after [Putirka et al., 2003]; 6 - position of figurative data points of the ternary feldspars from lamprophyres in the Ab-An-Ort diagram; 8 - position of figurative data points of the ternary feldspars from the melting zone of granite xenoliths in the $\mathrm{Ab}-\mathrm{An}$-Ort diagram. Isotherms in the $\mathrm{Ab}-\mathrm{An}$-Ort diagram for $\mathrm{P}=5$ kbar after [Nekvasil, 1992]. Complete analytical data tables are available on request to V.B. Khubanov (khubanov@mail.ru). 

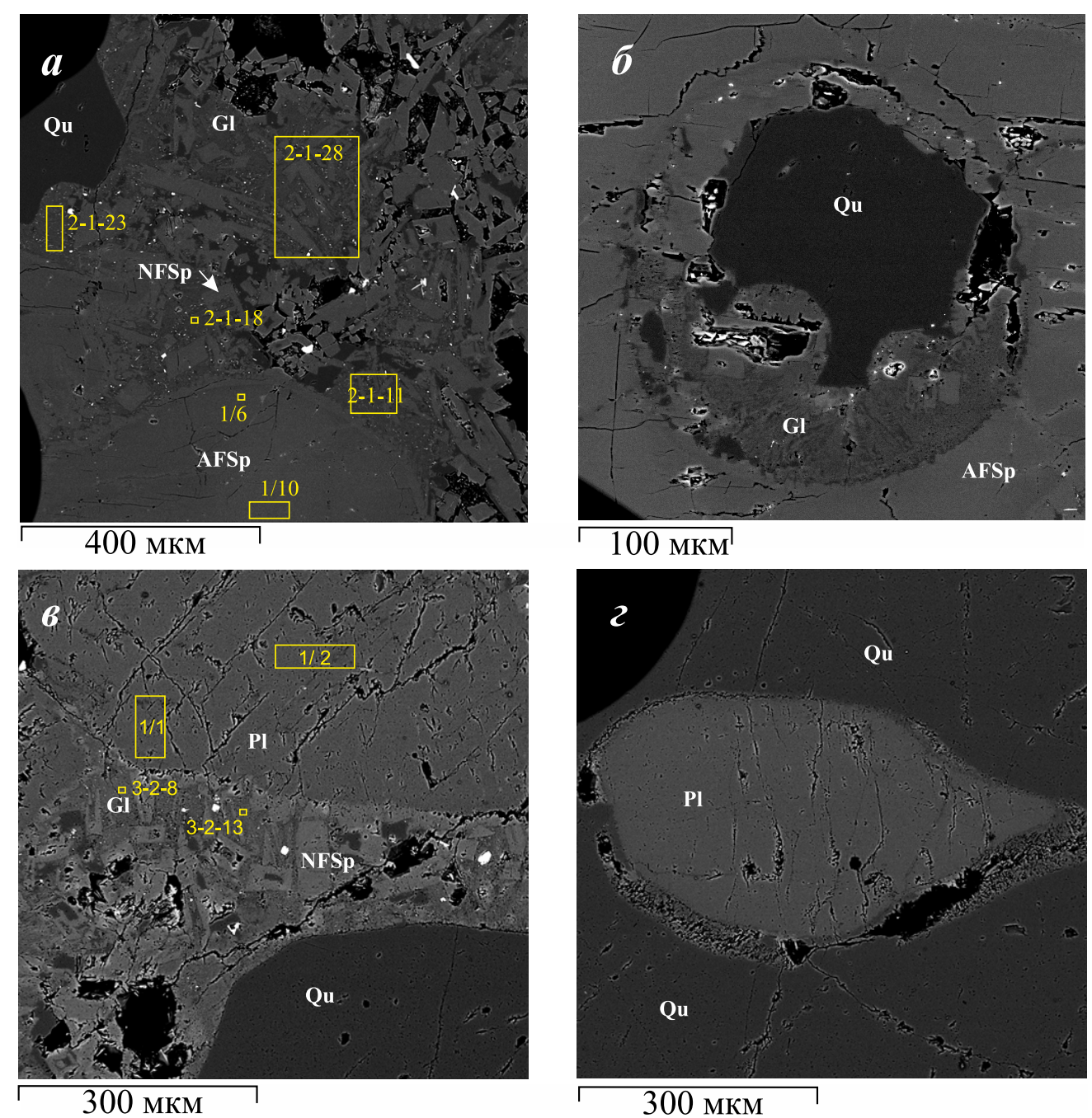

Рис. 5. Цифровые изображения шлифов, полученных с помощью растрового электронного микроскопа в режиме обратно-рассеянных электронов (BSE).

Образец щелочно-полевошпатового гранита P40A: $a$ - микрофельзит между кварцем и щелочным полевым шпатом ксенолита, состоящий из стекла и микролитов новообразованного щелочного полевого шпата; б - включение кварца в щелочном полевом шпате, между ними наблюдается зона из стекла. Образец GP14-10: в - микрофельзит между плагиоклазом и кварцем плагиогранитного ксенолита; 2 - включение плагиоклаза в кварце, между ними наблюдается тонкая зона перекристаллизации плагиоклаза. Буквенные обозначения, как на рисунке 3. Квадратами выделены примеры зон растрового анализа электронным сканирующим микроскопом, цифрами указаны столбцы с элементным составом в таблице 1.

Fig. 5. Digital images of microsections obtained using a scanning electron microscope mode in the BSE mode.

P40 specimen of alkaline feldspar granite: $a$ - microfelsite between quartz and alkaline feldspar xenolith, which consists of glass and microlites of young alkaline feldspar; $\sigma$ - inclusion of quartz in alkaline feldspar, separated by a zone of glass. GP14-10 specimen: 8 - microfelsite between plagioclase and quartz of plagiogranite xenolith; 2 - inclusion of plagioclase in quartz, separated by a thin zone of plagioclase recrystallization. Letters - same as in Fig. 3. Boxes - examples of the zones of raster analysis with an electronic scanning microscope. Numbers indicate the columns with elemental composition data in Table 1.

кристаллов относительно богата анортитовой молекулой, к периферии увеличивается доля альбитовой составляющей. С внешней стороны зерна тройного полевого шпата оконтурены щелочнополевошпатовой каймой (см. рис. 3, в). Судя по положению фигуративных точек составов на тройной диаграмме An-Ab-Ort (рис. 4) кристаллизация полевого шпата происходила в диапазоне температур от $900{ }^{\circ} \mathrm{C}$ (центр) до $700{ }^{\circ} \mathrm{C}$ (край).
Внутри ксенолитов между слагающим их полевым шпатом и кварцем практически повсеместно может наблюдаться тонкая зона плавления, состоящая из стекла (см. рис. 3, 2) и микрофельзита (микролиты полевого шпата с интерстициальным стеклом и кварцем) (рис. 5, $a, 8$ ). Нужно отметить, что подобные реакционные соотношения между фазами наблюдаются на границах как кварцщелочной полевой шпат (рис. 5, a), так и кварц- 
плагиоклаз (рис. 5, в). Мощность этой зоны увеличивается от центра ксенолита, где составляет первые сотые доли миллиметра, к его периферии - до полмиллиметра. Кроме того, здесь зерна первичных минералов ксенолитов также имеют очертания, преимущественно повторяющие контуры соседних кристаллов, от которых отделены тонкой зоной микрофельзита или стекла. Нередко контур первичных кристаллов, особенно у кварца, осложнен заливообразными очертаниями, что предполагает частичное растворение минерала (рис. 5 , б). Реже на продолжении зон плавления на границе минералов ксенолита имеются участки, заполненные карбонатом, состав которого нами не исследовался.

По периферии полевого шпата наблюдается тонкая кайма новообразованного полевого шпата, хорошо выделяющаяся на BSE снимках, нередко в ней просматривается тонковолокнистое сложение, причем «волокна» ориентированы перпендикулярно линии очертания первичного минерала, вокруг которого развиты. Близкие по облику полевошпатовые оторочки также описаны в частично расплавленных ксенолитах Бургултайского штока Малохамардабанской вулканотектонической структуры [Zanvilevich et al., 1988; Zanvilevich, Litvinovsky, 1996], где интерпретировались как свидетельства образования щелочно-полевошпатового (сиенитового) расплава в результате плавления щелочного полевого шпата.

Кроме того, реакционная оторочка из стекла или микрофельзита наблюдается вокруг включений кварца в полевом шпате (рис. 5, б). В обратном соотношении, когда зерно полевого шпата заключено в кварце, между минеральными фазами также присутствует тонкая реакционная зона, состоящая только из полевого шпата (рис. 5,2$)$. Следует отметить, что в редких ксенолитах сиенитового состава реакционные отношения в виде микрофельзита и стекла менее развиты ввиду небольшого количества кварца, в частности на периферии, в контакте с вмещающим лампрофиром, не наблюдается микрофельзитовая и/или гломерогранулярная зона.

Первичный полевой шпат щелочно-полевошпатовых гранитных ксенолитов представлен щелочным полевым шпатом (см. табл. 1, рис. 6, a). Стекло, обнаруженное на границе кварца и калий-натровых полевых шпатов, имеет ультракислый $\left(\mathrm{C} \mathrm{SiO}_{2}\right.$ 77-82 мас. \%) щелочной состав с высоким коэффициентом агпаитности (Ка) - более единицы (табл. 3 , pис. $6,6,8)$. При этом отношение $\mathrm{K}_{2} \mathrm{O} / \mathrm{Na}_{2} \mathrm{O}$ близко к двум. Производные плавления плагиогранита, где полевой шпат - это андезин (см. табл. 1, рис. 6, a), также имеют ультракислый щелочной (Ка>1) состав, при значении отношения $\mathrm{K}_{2} \mathrm{O} / \mathrm{Na}_{2} \mathrm{O}$ от 2 до 4 (табл. 3, рис. 6, б, в). Нужно отметить, что новообразованные полевые шпаты, микролиты в микрофельзите представлены щелочным полевым шпатом $\left(\mathrm{Or}_{45-55}, \mathrm{Ab}_{44-55}, \mathrm{An}_{0-6}\right)$, который по химическому составу, с большим содержанием оксида калия, отличен от первичных полевых шпатов ксенолитов (см. табл. 1 , рис. $6, a$ ).

Согласно рекомендациям [Fromberg, 1980; Litvinovsky et al., 2006], кислые породы, в которых содержание $\mathrm{K}_{2} \mathrm{O}$ преобладает над $\mathrm{Na}_{2} \mathrm{O}$ более чем в два раза, следует считать ультракалиевыми, поэтому производные плавления нами отнесены к высоко- и ультракалиевым разностям. В них отношение $\mathrm{K}_{2} \mathrm{O} / \mathrm{Na}_{2} \mathrm{O}$, за редким исключением, варьируется от 1.7 до 3.0 (рис. 6, в).

Микрофельзит, т.е. смесь стекла, микролитов полевого шпата и кварца, по химическому составу близок к щелочному граниту, в котором калий также существенно преобладает над натрием (табл. 3, рис. 6, б, в).

\section{6. ВОЗРАСТ И ИЗОТОПНЫЙ СОСТАВ КИСЛОРОДА ГРАНИТОИДОВ ИЗ КСЕНОЛИТОВ}

$\mathrm{U}-\mathrm{Pb}$ изотопное датирование с помощью LA-ICPMS метода проведено для цирконов из ксенолита щелочно-полевошпатового гранита GP7-10. В этом образце кристаллы цирконов отмечены непосредственно в микрофельзите, зоне плавления (фото на рис. 7). Проведено измерение пяти цирконов в 20 точках (рис. 7, a). Результаты представлены на графике с конкордией, из которого видно, что часть определений (14 точек) имеет компактное скопление с конкордатным возрастом (методом

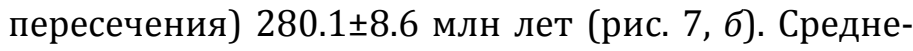
взвешенный $206 \mathrm{~Pb} / 238 \mathrm{U}$ возраст, скорректированный $207 \mathrm{~Pb}$-методом, для этих точек составляет $279.3 \pm 5.6$ (рис. 7, в). Остальные шесть определений сильно отклонены в сторону омоложения. Они, скорее всего, отражают потерю цирконом радиогенного свинца при прогреве в результате попадания ксенолита в лампрофировую магму. Становление лампрофировой дайки произошло 117-120 млн лет назад [Litvinovsky et al., 1989]. Нужно отметить, что полученная датировка совпадает с возрастом щелочно-полевошпатовых и щелочных сиенитов и гранитов раннекуналейского комплекса Забайкалья [Posokhov et al., 2005; Reichow et al., 2010].

Среди пород позднепалеозойско-мезозойских магматических комплексов Западного Забайкалья плагиограниты неизвестны, поэтому, скорее всего, плагиогранитные ксенолиты представляют собой фрагменты более древних магматитов, возможно раннепалеозойских, которые формировались в течение каледонского этапа геологического развития территории [Gordienko et al., 2012]. 

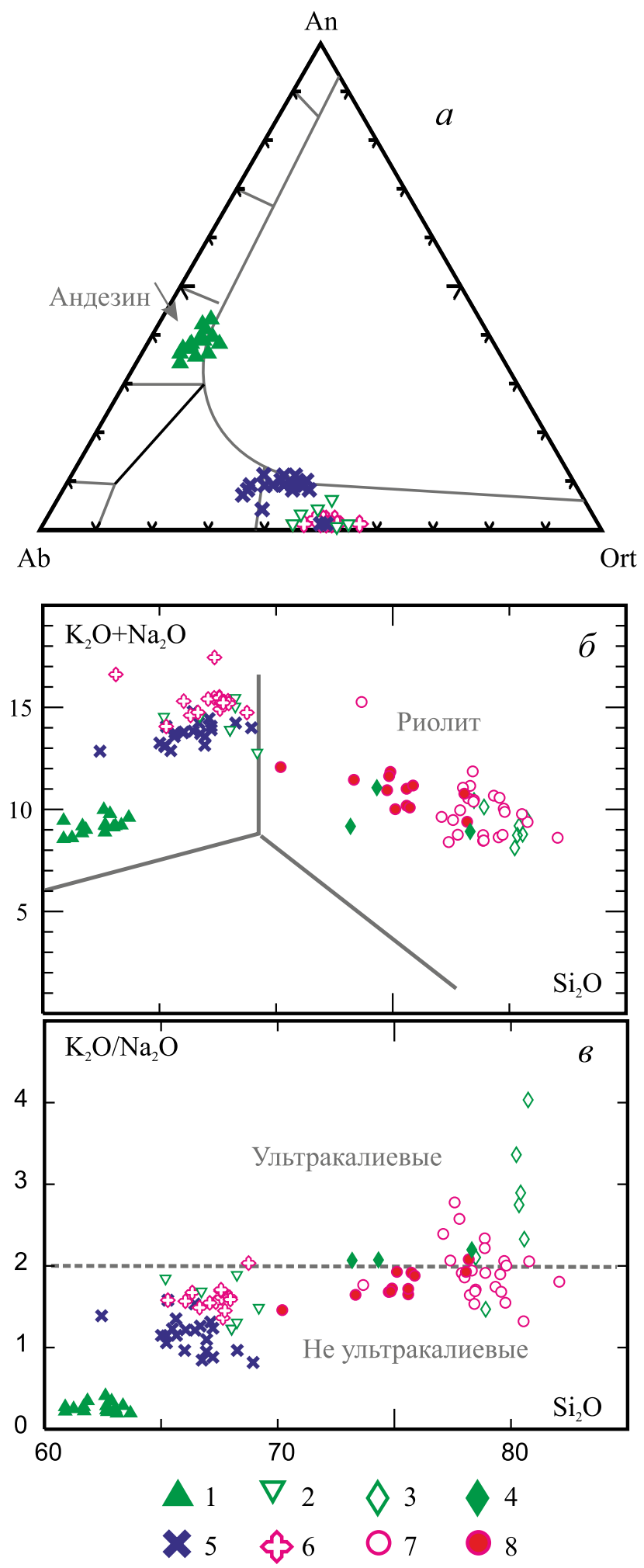

Результаты изучения изотопного состава кислорода минералов из гранитоидного (сиенитового) ксенолита и лампрофиров проиллюстрированы на рисунке 8. Значения $\delta^{18} 0$ для минералов (апатита, биотита, амфибола) из лампрофиров варьируются от 4.0 до $5.5 \%$, что укладывается в диапазон изотопного состава минералов и пород мантийного происхождения [Faure, 1986]. Для минералов ксе-
Рис. 6. Химический состав полевых шпатов и производных плавления ксенолитов Гусиноозерской дайки.

$a$ - положение фигуративных точек полевых шпатов гранитных ксенолитов на диаграмме Ab-An-Ort; $\sigma$ - положение фигуративных точек полевых шпатов микрофельзитов и стекол гранитных ксенолитов на диаграмме $\mathrm{SiO}_{2}-\left(\mathrm{K}_{2} \mathrm{O}+\mathrm{Na}_{2} \mathrm{O}\right)$; в - положение фигуративных точек полевых шпатов микрофельзитов и стекол гранитных ксенолитов на диаграмме $\mathrm{SiO}_{2}-\left(\mathrm{K}_{2} \mathrm{O} / \mathrm{Na}_{2} \mathrm{O}\right)$. Ксенолит плагиогранита (1-4): 1 - первичный плагиоклаз, 2 - новообразованный щелочной полевой шпат, 3 - стекло, 4 - микрофельзит (смесь стекла, новообразованного полевого шпата и кварца); ксенолит щелочно-полевошпатового гранита (5-8): 5 - первичный щелочной полевой шпат, 6 - новообразованный щелочной полевой шпат, 7 - стекло, 8 - мирофельзит (смесь стекла, новообразованного полевого шпата и кварца). Поле риолита на диаграмме (б) дано по [Le Bas et al., 1986]. Граница кислых ультракалиевых пород на диаграмме (в) дано по [Fromberg, 1980; Litvinovsky et al., 2006].

Fig. 6. Chemical compositions of feldspars and products from melting of xenoliths, Gusinoozerskaya dyke.

$a$ - positions of figurative data points of feldspars in granite xenoliths in the Ab-An-Ort diagram; $\sigma$ - positions of figurative data points of microfelsite feldspars and granite xenolith glass in the $\mathrm{SiO}_{2}-\left(\mathrm{K}_{2} \mathrm{O}+\mathrm{Na}_{2} \mathrm{O}\right)$ diagram; $в$ - positions of figurative data points of microfelsite feldspars and granite xenolith glass in the $\mathrm{SiO}_{2}-\left(\mathrm{K}_{2} \mathrm{O} / \mathrm{Na}_{2} \mathrm{O}\right)$ diagram. Xenolith of plagiogranite (1-4): 1 - primary plagioclase, 2 - young alkaline feldspar, 3 - glass, 4 - microfelsite (mixture of glass, young feldspar and quartz). Xenolith of alkaline-feldspar granite (5-8): 5 - primary alkaline feldspar; 6 - young alkaline feldspar, 7 - glass, 8 - microfelsite (mixture of glass, young feldspar and quartz). The rhyolite field in diagram (б) after [Le Bas et al., 1986]. The boundary of acidic ultrapotassic rocks in diagram (8) after [Fromberg, 1980; Litvinovsky et al., 2006].

нолита $\delta^{18} 0$ составляет: для апатита - $7.2 \%$, клинопироксена - 7.8 \%о и полевого шпата - $9.1 \%$.

Таким образом, согласно петрографической характеристике и U-Pb изотопному возрасту, гранитоидные ксенолиты представляют собой фрагменты ранне- и позднепалеозойских магматических образований с изотопным составом кислорода, отвечающим коровому источнику. 
T а б л и ц а 3. Представительные химические анализы стекол и микрофельзитов гранитных ксенолитов Гусиноозерской дайки, полученные с помощью сканирующего электронного микроскопа LEO-1430 VP

$\mathrm{T}$ a b l e 3. Representative chemical analysis of glass and microfelsite from granite xenoliths in the Gusinoozerskaya dyke, using a LEO-1430 VP scanning electron microscope

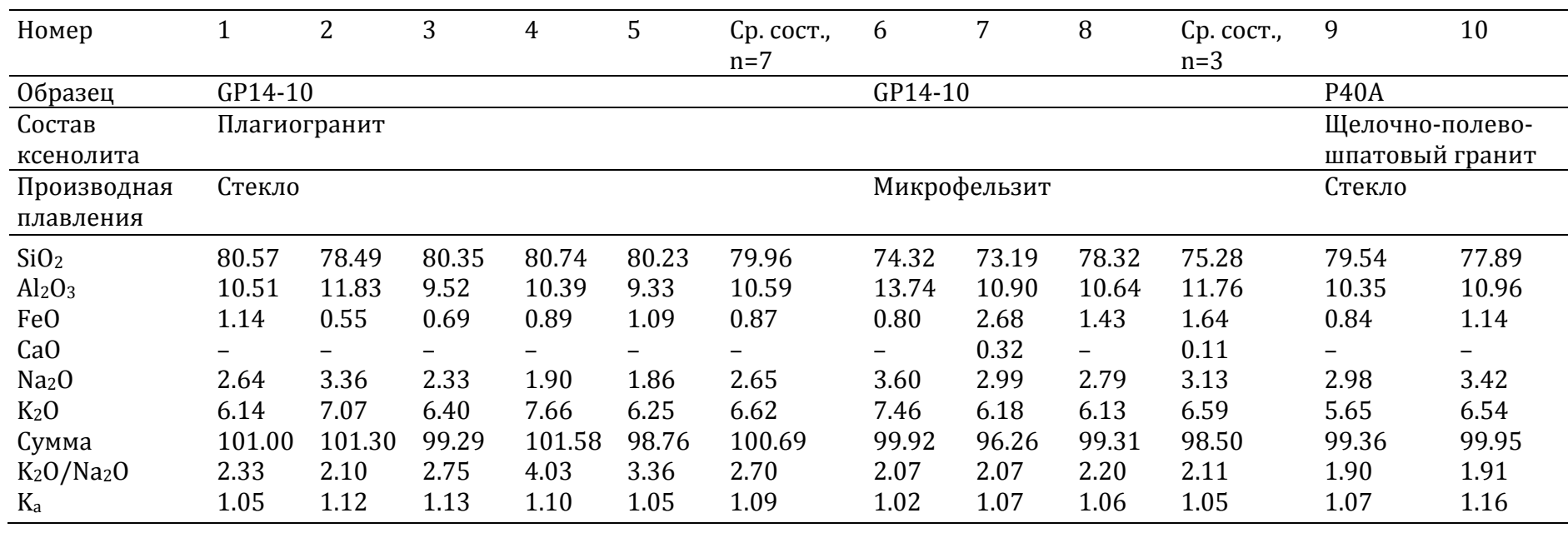

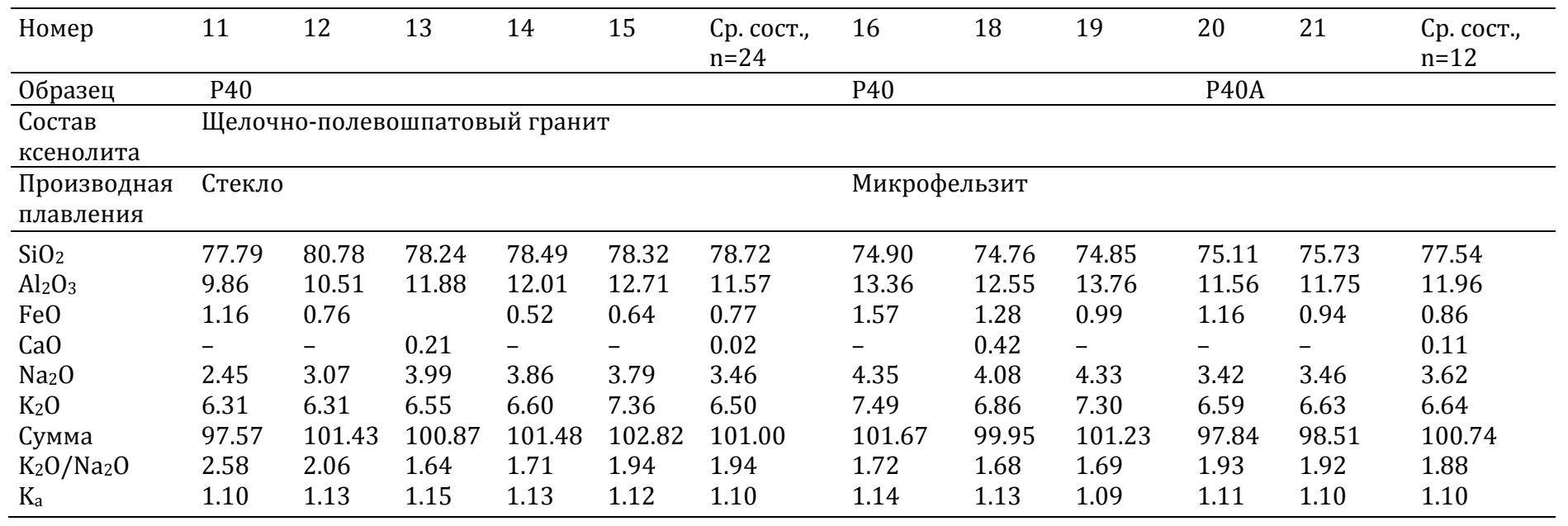

П р и м е ч а н и е. Ср. сост. - средний состав, $\mathrm{n}$ - количество усредненных анализов, прочерк - ниже пределов обнаружения, $\mathrm{K}_{\mathrm{a}}=\left(\mathrm{K}_{2} \mathrm{O}+\mathrm{Na}_{2} \mathrm{O}\right) / \mathrm{Al}_{2} \mathrm{O}_{3}$ в молекулярных количествах.

$\mathrm{N}$ o t e. Cp. cocт. - average composition; $\mathrm{n}$ - number of averaged assays; dash - below detection limits, $\mathrm{K}_{\mathrm{a}}=\left(\mathrm{K}_{2} \mathrm{O}+\mathrm{Na}_{2} \mathrm{O}\right) / \mathrm{Al}_{2} \mathrm{O}_{3}$ in molecular quantities.

\section{7. УСЛОВИЯ ПЛАВЛЕНИЯ}

Внутреннее строение ксенолитов неоднородное. В периферийной части они окружены микрофельзитовой каймой (реакционной зоной) мощностью до первых миллиметров. В контакте с вмещающей породой первичные минералы ксенолита могут отсутствовать, что, вероятно, обусловлено их полным плавлением. С удалением от контакта и в случае частичного плавления минералов ксенолита реакционная зона приобретает гломерогранулярную структуру. Далее мощность зон, сложенных микрофельзитом и стеклом, постепенно уменьша- ется и внутри ксенолита она составляет сотни десятки микронов между первичными полевыми шпатами и кварцем. Такие особенности ксенолитов свидетельствуют о том, что они испытали частичное (парциальное) плавление именно в контакте с горячей вмещающей лампрофировой (щелочномафической) магмой.

Об этом также говорят признаки обмена веществом между щелочно-мафической магмой и новообразованным расплавом: 1) присутствие интерстиционного кварца во вмещающей лампрофировой породе вблизи контакта с ксенолитами, хотя изначально лампрофировая магма характеризова- 

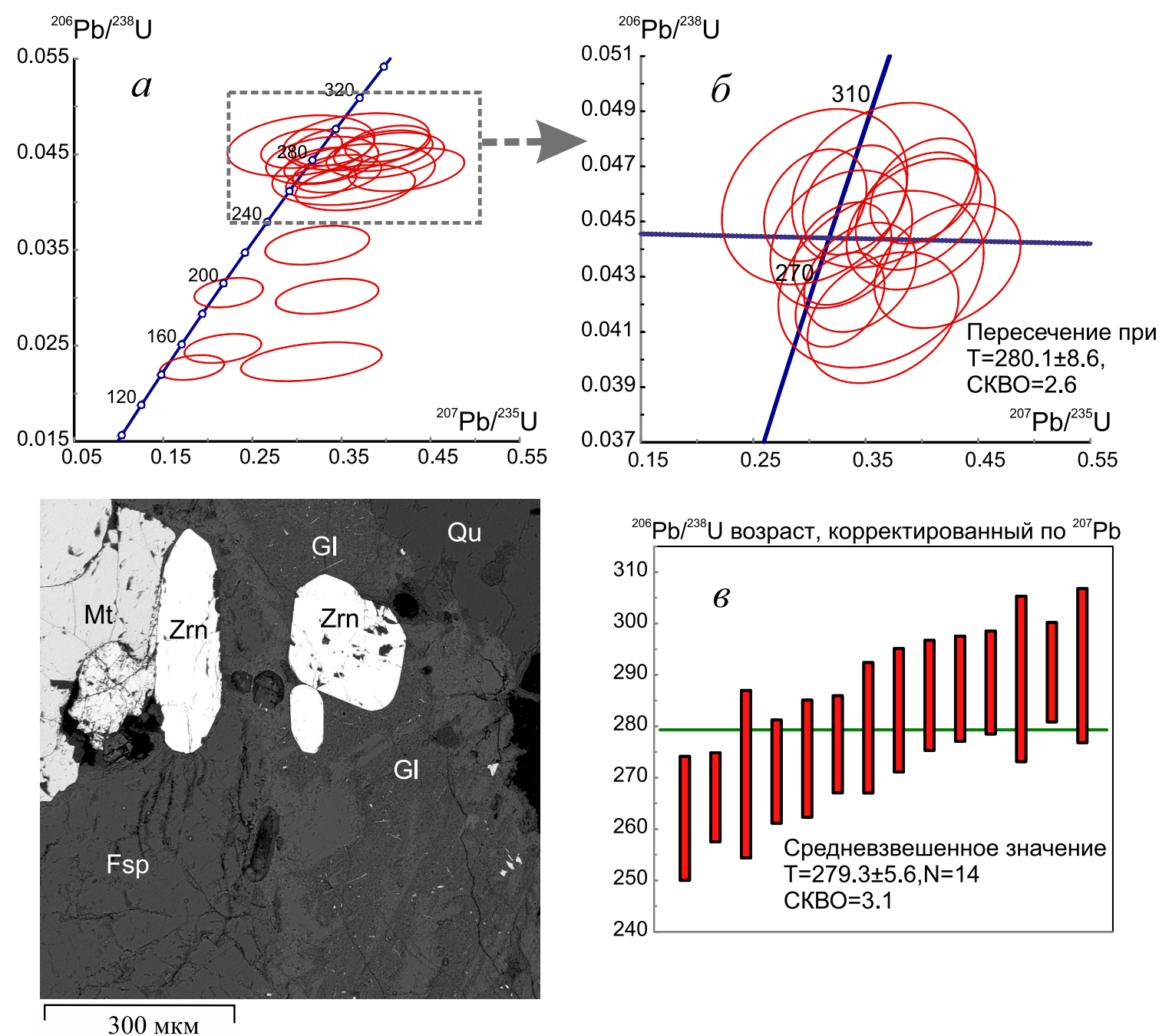

Pис. 7. U-Pb возраст цирконов из гранитного ксенолита (обр. GP7-10) лампрофировой Гусиноозерской дайки.

$a$ - график с изотопными отношениями ${ }^{207} \mathrm{~Pb} / 235 \mathrm{U}$ и $206 \mathrm{~Pb} / 238 \mathrm{U}$ и конкордией; $\sigma$ - конкордантный возраст для 14 проанализированных точек, построенный методом пересечения; в - средневзвешенный возраст по отношению ${ }^{206} \mathrm{~Pb} /{ }^{238} \mathrm{U}$, скорректированный на обыкновенный свинец методом 207Pb-коррекции. В левом нижнем углу - BSE-фотография шлифа образца GP7-10. Буквенные обозначения: Mt - магнетит, FSp - полевой шпат, Qu - кварц, Zrn - циркон, Gl - стекло.

Fig. 7. U-Pb age of zircon from granitic xenolith (GP7-10 specimen), Gusinoozerskaya lamprophiric dyke.

$a$ - plot with isotopic ratios ${ }^{207} \mathrm{~Pb} /{ }^{235} \mathrm{U}$ and ${ }^{206} \mathrm{~Pb} / 238 \mathrm{U}$ and concordia; $\sigma$ - concordant age for 14 analysed points (crossing method); 8 average age in relation to ${ }^{206} \mathrm{~Pb} / 238 \mathrm{U}$, corrected for ordinary lead by the ${ }^{207} \mathrm{~Pb}$-correction method. Lower left insert: BSE-image of the microsection of GP7-10 specimen. Mt - magnetite, Fsp - feldspar, Qu - quartz, Zrn - zircon, Gl - glass.

лась нефелин-нормативным составом; 2) наличие в микрофельзитовой зоне ксенолита тройного полевого шпата. В первом случае, по-видимому, имеет место диффузия кремния из кислого расплава в мафическую магму. Во втором - кристаллы тройного полевого шпата были захвачены из мафической магмы, поскольку трудно представить их кристаллизацию из низкокальциевого новообразованного кислого расплава.

Исходя из сказанного вполне очевидно, что условия плавления ксенолитов в большей степени контролировались интенсивными параметрами кристаллизации щелочно-мафической магмы, с ко- торой они контактировали. Согласно определениям [Shadaev, 2001], субликвидусная температура щелочно-мафической магмы составляла 1100 $1000{ }^{\circ} \mathrm{C}$, а субсолидусная - 800-700 ${ }^{\circ} \mathrm{C}$. Следует отметить, что температуры кристаллизации ксеногенных зональных тройных полевых шпатов из микрофельзитовой зоны (зона плавления) ксенолитов близки к условиям кристаллизации тройных полевых шпатов из лампрофиров (см. рис. 3), поэтому вероятная температура плавления гранитного ксенолита была близка к самой низкой температуре кристаллизации тройных полевых шпатов (около $700{ }^{\circ} \mathrm{C}$ ). 


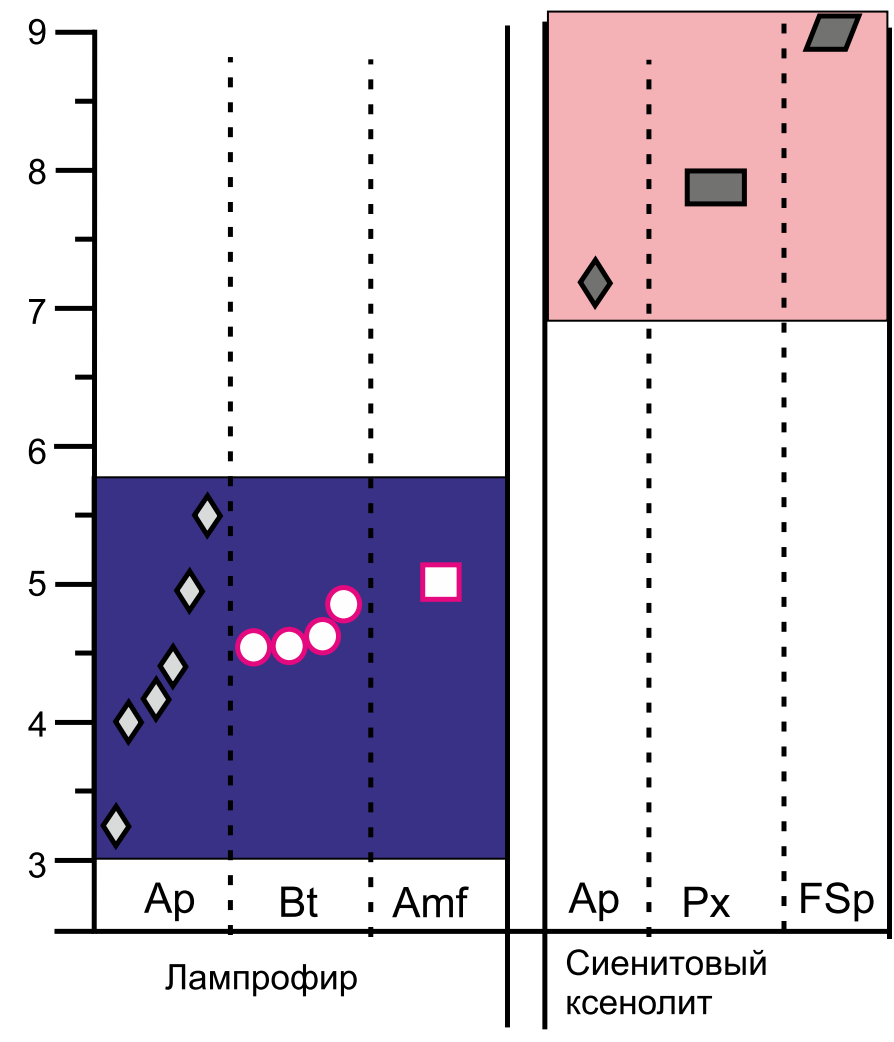

Рис. 8. Изотопный состав кислорода в минералах лампрофиров (синее поле) и ксенолитов (розовое поле) Гусиноозерской дайки.

Обозначения: Ap - апатит (ромб), Bt - биотит (круг), Amf амфибол (квадрат), Рx - пироксен (прямоугольник), Fsp полевой шпат (призма).

Fig. 8. Isotopic compositions of oxygen in the minerals of lamprophyres (blue field) and xenoliths (pink field) of Gusinoozerskaya dyke.

Ap - apatite (rhombus), Bt - biotite (circle), Amf - amphibole (square), Px - pyroxene (rectangle), Fsp - feldspar (prism).

Вполне вероятно, что из кристаллизующейся щелочно-мафической магмы выделялся флюид в виде самостоятельной фазы. Об этом косвенно свидетельствуют масштабы экзоконтактовых изменений осадочных пород, вмещающих Гусиноозерскую дайку, которые невозможны без участия горячего флюида. Кроме того, согласно экспериментальным данным [Sisson, Grove, 1993], наличие фенокристаллов биотита и амфибола, а также отсутствие плагиоклаза среди вкрапленников лампрофиров указывают на то, что изначально мафическая магма была существенно обогащена водой (не менее 4-6 мас. \%). Помимо воды заметную роль среди летучих компонентов, возможно, играли галогены и углекислота. На их присутствие указывают содержания фтора и хлора в составе апатита [Shadaev, 2001] и интерстиционный карбонат в лампрофирах, а также карбонат среди продуктов плавления ксенолитов. Следует добавить, что, поскольку мафиче- ская магма была щелочной, отделившиеся растворы, скорее всего, также были обогащены щелочами.

В свете изложенного можно предположить, что плавление ксенолитов происходило в присутствии свободного флюида, который выделялся из кристаллизующейся вмещающей щелочно-мафической магмы. В частности, в пользу этого говорит тот факт, что в ксенолитах вокруг кварцевых включений в первичном полевом шпате наблюдается кайма оплавления (см. рис. 5, б), но она отсутствует при обратном соотношении этих минералов (см. рис. 5, 2). Это можно объяснить тем, что полевые шпаты относительно проницаемы для растворов, по сравнению с кварцем, и летучие компоненты, главным образом вода, играют флюсующую роль и понижают температуру плавления. Так как плотная структура кварца плохо проницаема для флюида, вокруг полевошпатового включения в кварце имела место только его частичная перекристаллизация (см. рис. 5, г) под воздействием кондуктивного прогрева.

Таким образом, парциальное плавление гранитоидных ксенолитов происходило при тепловом и флюидном воздействии вмещающей мафической магмы. С учетом того, что новообразованный расплав в ксенолитах местами не успел кристаллизоваться и остался в виде стекла, остывание магматической системы происходило быстро, по-видимому, в близповерхностных условиях.

\section{8. ФАКТОРЫ, ОБУСЛОВИВШИЕ ВЫСОКО- И УЛЬТРАКАЛИЕВЫЙ СОСТАВ ПАРЦИАЛЬНЫХ ВЫПЛАВОК}

Существует разнообразие гипотез формирования высоко- и ультракалиевых кислых пород: 1) ликвация щелочно-риолитового расплава на калиевую и натриевую жидкие фазы [Fromberg, 1980]; 2) плавление при высоких температурах породы, состоящей исключительно из щелочного полевого шпата [Stuart, 1983]; 3) кристаллизация калиевого полевого шпата и удаление остаточных «натриевых» жидкостей посредством механизмов стрессовой сепарации (фильтр-прессинг и механизм порога жесткого просачивания) [Litvinovsky et al., 2006]; 4) накопление калия при наложенном низкотемпературном метасоматозе (адуляризация стекла и плагиоклаза) [Popov, Nikolaenko, 1988; Munhá et al., 1980; Ennis et al., 2000; Mishin, 2006]; 5) модель флюидно-магматического взаимодействия. Последняя точка зрения предполагает участие сложных щелочно-галоидных растворов при плавлении гранитных (коровых) субстратов [Bai, Koster van Groos, 1999; Aranovich et al., 2013] и при кристаллизацион- 


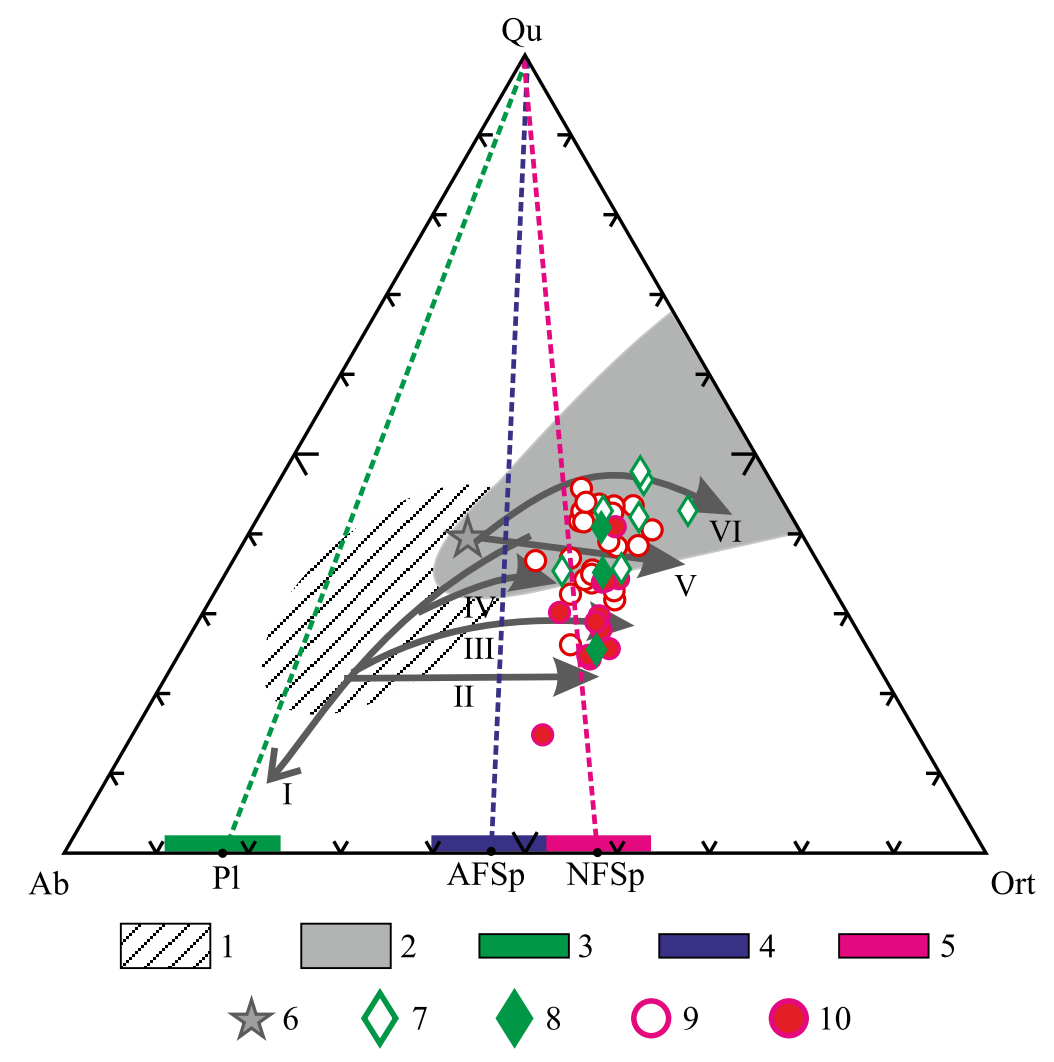

Рис. 9. Положение фигуративных точек CIPW-нормированных составов производных плавления гранитных ксенолитов Гусиноозерской дайки на диаграмме Ab-Qu-Ort.

1, 2 - поля составов онгонитов (1) и эльванов (2) по [Antipnin et al., 2002; Vladimirov et al., 2007]; 3-5 - вариации составов полевых шпатов гранитных ксенолитов на оси Ab-Ort: плагиоклазов из плагиогранитов (3), калий-натровых полевых шпатов из щелочно-полевошпатовых гранитов (4), новообразованных полевых шпатов (5); 6 - состав гаплогранита по [Tuttle, Bowen, 1958]; 7-10 составы производных плавления гранитных ксенолитов: стекла из плагиогранита (7), микрофельзита из плагиогранита (8), стекла из щелочно-полевошпатового гранита (9) и микрофельзита из щелочно-полевошпатового гранита (10). Положения средних составов полевых шпатов указаны точками пересечения пунктирных линий, исходящих из вершины Qu: Pl - cредний состав плагиоклаза из плагиогранита; AFSp - средний состав калий-натрового полевого шпата из щелочно-полевошпатового гранита; NFSp - средний состав новообразованного щелочного полевого шпата. Стрелками и римскими цифрами указаны тренды вариаций составов расплавов-минимумов по экспериментальным данным: I и II - по [Johannes, Holtz, 1996] при участии Н 20 (I), $\mathrm{H}_{2} \mathrm{O}-\mathrm{CO}_{2}$ (II) и различном давлении; III и IV - по [Aranovich et al., 2013] при $\mathrm{H}_{2} \mathrm{O}-\mathrm{NaCl}-\mathrm{KCl}$ при 10 кбар (III) и 6 кбар (IV); V - расчетный по [Sokolova, Smirnov, 2014] при $\mathrm{H}_{2} \mathrm{O}-\mathrm{KCl}$; VI - тренд суммированных данных из [Bai, Koster van Groos, 1999] при Н20-KCl, $\mathrm{H}_{2} \mathrm{O}-\mathrm{NaCl}-\mathrm{KCl}, \mathrm{H}_{2} \mathrm{O}-\mathrm{Na}_{2} \mathrm{CO}_{3}$ и $\mathrm{H}_{2} \mathrm{O}-\mathrm{Na}_{2} \mathrm{CO}_{3}-\mathrm{K}_{2} \mathrm{CO}_{3}$ и давлении от 1 до 4 кбар.

Fig. 9. Locations of figurative data points of CIPW-normalized compositions of products from melting of granite xenoliths in the Gusinoozerskaya dyke in the $\mathrm{Ab}-\mathrm{Qu}$-Ort diagram.

1,2 - fields of compositions of ongonites (1) and elvanes (2) [Antipnin et al., 2002; Vladimirov et al., 2007]; 3-5 - variations in compositions of feldspars of granite xenoliths on the Ab-Ort axis: 3 - plagioclase plagiogranites, $4-\mathrm{K}$-Na feldspars from alkaline feldspar granites, 5 young feldspars; 6 - composition of haplogranite after [Tuttle, Bowen, 1958]; 7-10 - compositions of products from melting of granite xenoliths: 7 - glass from plagiogranite, 8 - microfelsite from plagiogranite, 9 - glass from alkaline feldspar granite, 10 - microfelsite from alkaline feldspar granite. The position of the average compositions of feldspars is indicated by the points of suppression of the dashed lines emanating from the vertex Qu: Pl - average composition of plagioclase from plagiogranite; AFSp - average composition of K-Na feldspar from alkaline-feldspar granite; NFSp - average composition of young alkaline feldspar. Arrows and Roman numerals mark the trends of variations in the compositions of minimum melts, according to the experimental data: I, II - after [Johannes, Holtz, 1996] (I - $\mathrm{H}_{2} \mathrm{O}$ (I), II $\mathrm{H}_{2} \mathrm{O}-\mathrm{CO}_{2}$ at different pressure rates); III, IV - after [Aranovich et al., 2013] (III - $\mathrm{H}_{2} \mathrm{O}-\mathrm{NaCl}-\mathrm{KCl}$ at $10 \mathrm{kbar} ; \mathrm{IV}-\mathrm{H}_{2} \mathrm{O}-\mathrm{NaCl}-\mathrm{KCl}$ at $6 \mathrm{kbar}$ ); $\mathrm{V}$ - estimated after [Sokolova, Smirnov, 2014] $\left(\mathrm{H}_{2} \mathrm{O}-\mathrm{KCl}\right)$; VI - trend of the summary data after [Bai, Koster van Groos, 1999] ( $\mathrm{H}_{2} \mathrm{O}-\mathrm{KCl}, \mathrm{H}_{2} \mathrm{O}-$ $\mathrm{NaCl}-\mathrm{KCl}, \mathrm{H}_{2} \mathrm{O}-\mathrm{Na}_{2} \mathrm{CO}_{3}$, and $\mathrm{H}_{2} \mathrm{O}-\mathrm{Na}_{2} \mathrm{CO}_{3}-\mathrm{K}_{2} \mathrm{CO}_{3}$ at 1 to $\left.4 \mathrm{kbar}\right)$.

ной дифференциации кислых магм [Antipin et al., 2002; Vladimirov et al., 2007; Sokolova et al., 2011].

На примере ксенолитов Гусиноозерской дайки показано, что высокоультракалиевые кислые производные сформировались также во флюидно-маг- матической системе, поэтому их нормированные составы вынесены на тройную диаграмму Ort-Ab$\mathrm{Qu}$ для сопоставления с результатами экспериментального плавления гранитов (рис. 9). Установлено два типа субстратов (пород), испытавших 
контактовое плавление: кварц-щелочно-полевошпатовый субстрат (щелочно-полевошпатовый гранит), нормированный состав которого на тройной диаграмме находится вдоль линии AFs-Qu (рис. 9), и кварц-плагиоклазовый субстрат (плагиогранит) (положение состава на тройной диаграмме контролируется линией Pl-Qu). Фигуративные точки составов производных плавления обоих типов ксенолитов накладываются друг на друга, а также на тренды вариаций составов экспериментальных расплавов минимумов, полученных при плавлении гаплогранита и лейкогранита в присутствии щелочно-хлоридных и щелочно-углекислых флюидов. Кроме того, они перекрывают поле состава редкометалльных ультракалиевых гранитов, эльванов (рис. 9).

В Гусиноозерской дайке в близповерхностных условиях парциальное плавление испытали различные по составу ксенолиты, а эксперименты проводились только для гаплогранита и лейкогранита и при давлениях верхне- и среднекоровых глубин, тем не менее сходимость составов экспериментальных и природных ультракалиевых расплавов очевидна. Данный факт наводит на мысль, что обогащенность калием производных плавления в меньшей степени зависит от состава протолитового субстрата и глубины плавления (в диапазоне от дневной поверхности до средней коры), а ведущим фактором является состав сосуществующего флюида. Вероятно, это обусловлено тем, что в системах щелочно-хлоридный флюид - кислый расплав и щелочно-углекислый флюид - кислый расплав коэффициент распределения калия между флюидом и расплавом меньше, чем коэффициент распределения натрия, поэтому в расплавах накапливается калий, а во флюиде - натрий [Bai, Koster van Groos, 1999; Aranovich et al., 2013].

\section{9. ОЦЕНКА ГЕОТЕКТОНИЧЕСКИХ УСЛОВИЙ ФОРМИРОВАНИЯ УЛЬТРАКАЛИЕВЫХ КИСЛЫХ РАСПЛАВОВ}

Гусиноозерская лампрофировая дайка простирается параллельно борту юрско-меловой рифтогенной одноименной впадины и фиксирует меловую стадию тектонического растяжения. Изотопный состав кислорода в минералах (см. рис. 8), а также валовый Sr-Nd изтопный состав [Andryushchenko et al., 2010] лампрофиров свидетельствуют об их мантийном магматическом источнике. Соответственно флюиды, обусловившие плавление гранитных ксенолитов Гусиноозерской дайки, также имеют мантийный генезис. Нужно отметить, что в целом для позднепалеозойско-мезозойского внутриконтинентального базитового магматизма За- падного Забайкалья отмечается специфический водно- и калий-обогащенный источник - флогопитсодержащая мантия [Tsygankov et al., 2010; Tsygankov et al., 2016].

Из примера изучения гранитных ксенолитов Гусиноозерской дайки и экспериментальных работ следует, что формирование ультракалиевых кислых расплавов происходит при плавлении вещества коры под воздействием горячих мантийных щелочно-хлоридных и/или щелочно-углекислых флюидов. Представляется, что наиболее благоприятные условия возникновения необходимого количества подобных флюидов и плавления гранитоидных вмещающих пород будут над апикальными частями промежуточных камер с флюидообогащенными щелочно-мафическими магмами. В геотектоническом аспекте такие камеры возможны во внутриконтинентальных обстановках растяжения и на средне- и верхнекоровых уровнях глубины, где наиболее вероятно декомпрессионное флюидоотделение.

Дополнительным подтверждением данных выводов служат проявления эльванов (редкометалльные ультракалиевые граниты), которые образуют небольшие гипабиссальные массивы, штоки, дайки в структурах растяжения и имеют тесную пространственно-временную и парагенетическую связь с щелочно-базальтовыми, монцонитовыми и лампрофировыми субвулканитами [Antipin et al., 2002; Vladimirov et al., 2007]. Кроме того, согласно данным о составе расплавных включений, мафические расплавы внутриконтинентальных рифтов в разы обогащены хлором и углекислотой относительно базальтоидов других обстановок [Naumov et al., 2004].

\section{0.ЗАКЛЮЧЕНИЕ}

Гранитные ксенолиты меловой Гусиноозерской лампрофировой дайки испытали частичное плавление в контакте с вмещающей щелочно-базитовой магмой. Продукты плавления по периферии ксенолитов представлены каймами (зонами) с микрофельзитовой, микрогранофировой, криптокристаллической гломерогранулярной структурой. Внутри ксенолитов на границе первичного полевого шпата и кварца наблюдается стекло.

Установлены два минеральных субстрата, претерпевших плавление: щелочной полевой шпат кварц (щелочно-полевошпат-гранитные ксенолиты) и плагиоклаз - кварц (плагиогранитные ксенолиты). Особенностью химического состава производных плавления является их повышенная калиевость с отношением $\mathrm{K}_{2} \mathrm{O} / \mathrm{Na}_{2} \mathrm{O} \geq 2$, которая обусловлена плавлением в присутствии щелочно-хлорид- 
ных и/или щелочно-углекислых растворов и в меньшей степени зависит от состава гранитоидного протолита.

Особенности условий плавления ксенолитов Гусиноозерской дайки дают основание полагать, что выплавление ультракалиевых расплавов также возможно над апикальными частями промежуточных щелочно-мафических камер на уровне средней и верхней континентальной коры в обстановках растяжения.

\section{1. БЛАГОДАРНОСТИ}

Статья подготовлена при поддержке Российского фонда фундаментальных исследований (проекты № 14-05-00498 и 14-05-00747).

\section{2. ЛИТЕРАTУРA / REFERENCES}

Andryushchenko S.V., Vorontsov A.A., Yarmolyuk V.V., Sandimirov I.V., 2010. Evolution of Jurassic-Cretaceous magmatism in the Khambin volcanotectonic complex (Western Transbaikalia). Russian Geology and Geophysics 51 (7), 734-749. https://doi.org/10.1016/j.rgg.2010.06.002.

Antipin V.S., Halls C., Mitichkin M.A., Scott P., Kuznetsov A.N., 2002. Elvans of Cornwall (England) and Southern Siberia as subvolcanic counterparts of subalkalic rare metal granites. Geologiya i Geofizika (Russian Geology and Geophysics) 43 (9), 847-857.

Aranovich L.Y., Newton R.C., Manning C.E., 2013. Brine-assisted anatexis: Experimental melting in the system haplogranite- $\mathrm{H}_{2} \mathrm{O}-\mathrm{NaCl}-\mathrm{KCl}$ at deep-crustal conditions. Earth and Planetary Science Letters 374, 111-120. https:// doi.org/10.1016/j.epsl.2013.05.027.

Bai T.B., Koster Van Groos A.F., 1999. The distribution of $\mathrm{Na}, \mathrm{K}, \mathrm{Rb}, \mathrm{Sr}, \mathrm{Al}, \mathrm{Ge}, \mathrm{Cu}, \mathrm{W}, \mathrm{Mo}$, La, and Ce between granitic melts and coexisting aqueous fluids. Geochimica et Cosmochimica Acta 63 (7-8), 1117-1131. https://doi.org/ 10.1016/S0016-7037(98)00284-1.

Buyantuev M.D., Khubanov V.B., Vrublevskaya T.T., 2017. U-Pb LA-ICP-MS dating of zircons from subvolcanics of the bimodal dyke series of the Western Transbaikalia: Technique, and evidence of the Late Paleozoic extension of the crust. Geodynamics \& Tectonophysics 8 (2), 369-384 (in Russian) [Буянтуев М.Д., Хубанов В.Б., Врублевская Т.T. $\mathrm{U}-\mathrm{Pb}$ LA-ICP-MS датирование цирконов из субвулканитов бимодальной дайковой серии Западного Забайкалья: методика, свидетельства позднепалеозойского растяжения земной коры // Геодинамика и тектонофизика. 2017. Т. 8. № 2. С. 369-384]. https://doi.org/10.5800/GT-2017-8-2-0246.

Ennis D.J., Dunbar N.W., Campbell A.R., Chapin C.E., 2000. The effects of K-metasomatism on the mineralogy and geochemistry of silicic ignimbrites near Socorro, New Mexico. Chemical Geology 167 (3-4), 285-312. https://doi.org/ 10.1016/S0009-2541(99)00223-5.

Faure G., 1986. Principles of Isotope Geology. John Wiley \& Sons, New York, 608 p. [Русский перевод: Фор Г. Основы изотопной геологии. М.: Мир, 1989. 590 с.].

Fromberg E.D., 1980. On the nature of ultrapotassic liparites. Doklady AN SSSR 253 (3), 685-687 (in Russian) [Фромберг Э.Д. О природе ультракалиевых липаритов // Доклады АН СССР. 1980. Т. 253. № 3. С. 685-687].

Gordienko I.V., Kovach V.P., Elbaev A.L., Kotov A.B., Sal'nikova E.B., Reznitskii L.Z., Yakovleva S.Z., Anisimova I.V., 2012. Collisional granitoids of the Dzhida zone of the Central Asian fold belt, Southwestern Transbaikalia: Age and conditions of the formation. Petrology 20 (1), 40-58. https://doi.org/10.1134/S086959111201002X.

Haweks L., 1929. On a partially fused quartz-feldspar-rock and on glomerogranular texture. Mineralogical Magazine 22 (127), 163-174. https://doi.org/10.1180/minmag.1929.022.127.01.

Hersum T.G., Marsh B.D., Simon A.C., 2007. Contact partial melting of granitic country rock, melt segregation, and re-injection as dikes into Ferrar Dolerite Sills, McMurdo Dry Valleys, Antarctica. Journal of Petrology 48 (11), 2125-2148. https://doi.org/10.1093/petrology/egm054.

Huppert H.E., Sparks R.S., 1988. The generation of granitic magmas by intrusion of basalt into continental crust. Journal of Petrology 29 (3), 599-624. https://doi.org/10.1093/petrology/29.3.599.

Ivanov V.G., Yarmolyuk V.V., 1996. An Early Cretaceous tephrite-phonolite association on the southern slope of the Lesser Khamardaban range, Western Transbaikal region. Transactions of the Russian Academy of Sciences - Earth Science Sections 349 (6), 895-898.

Jahn B.M., Litvinovsky B.A., Zanvilevich A.N., Reichow M., 2009. Peralkaline granitoid magmatism in the MongolianTransbaikalian Belt: Evolution, petrogenesis and tectonic significance. Lithos 113 (3-4), 521-539. https://doi.org/ 10.1016/j.lithos.2009.06.015.

Johannes W., Holtz F., 1996. Petrogenesis and Experimental Petrology of Granitic Rocks. Springer, Heidelberg, 335 p. https://doi.org/10.1007/978-3-642-61049-3.

Khubanov V.B., Buyantuev M.D., Tsygankov A.A., 2016. U-Pb dating of zircon from PZ3-MZ igneous complexes of Transbaikalia by sector-field mass spectrometry with laser sampling: technique and comparison with SHRIMP. Russian Geology and Geophysics 57 (1), 190-205. https://doi.org/10.1016/j.rgg.2016.01.013.

Khubanov V.B., Vrublevskaya T.T., Tsyrenov B.Ts., Tsygankov A.A., 2015. Formation of the trachybasalt-trachyte bimodal series of the Malo-Khamardaban volcanotectonic complex, southwestern Transbaikalia: Role of fractional crystallization and magma mixing. Petrology 23 (5), 451-479. https://doi.org/10.1134/S0869591115040037. 
Le Bas M.J., Le Maitre R.W., Streckeisen A., Zanettin B., 1986. A chemical classification of volcanic rocks based on total alkaline-silica diagram. Journal of Petrology 27 (3), 745-750. https://doi.org/10.1093/petrology/27.3.745.

Litvinovsky B.A., Karmanov N.S., Vapnik E., 2006. Genesis of ultrapotassic quartz porphyry in the Northern ArabianNubian shield. Geologiya i Geofizika (Russian Geology and Geophysics) 47 (11), 1103-1127.

Litvinovsky B.A., Posokhov V.F., Shadaev M.G., Shalagin V.L., 1989. New data on the age of the Early Cretaceous volcanic rocks of the Western Transbaikalia (Rb-Sr and K-Ar datings). Doklady AN SSSR 308 (4), 946-949 (in Russian) [Литвиновский Б.А., Посохов В.Ф., Шадаев М.Г., Шалагин В.Л. Новые данные о возрасте раннемеловых вулканитов Западного Забайкалья (Rb-Sr и K-Ar даты) // Доклады АН СССР. 1989. Т. 308. № 4. С. 946-949].

Litvinovsky B.A., Tsygankov A.A., Jahn B.M., Katzir Y., Be'eri-Shlevin Y., 2011. Origin and evolution of overlapping calcalkaline and alkaline magmas: The Late Palaeozoic post-collisional igneous province of Transbaikalia (Russia). Lithos 125 (3-4), 845-874. https://doi.org/10.1016/j.lithos.2011.04.007.

Litvinovsky B.A., Zanvilevich A.N., Alakshin A.M., Podladchikov Y.Y., 1993. The Angara-Vitim Batholith, the Largest Granitoid Pluton. OIGGM SO RAN, Novosibirsk, 141 p. (in Russian) [Литвиновский Б.А., Занвилевич А.Н., Алакшин А.М., Подладчиков Ю.Ю. Ангаро-Витимский батолит - крупнейший гранитоидный плутон. Новосибирск: Изд-во ОИГГМ СО РАН, 1993. 141 с.].

Mishin L.F., 2006. The nature and prospecting implications for ultrapotassic rhyolites as exemplified by epithermal gold-silver deposits of the Far East. Tikhookeanskaya Geologiya (Russian Journal of Pacific Geology) 25 (6), 30-39 (in Russian) [Мишин Л.Ф. Природа и поисковое значение ультракалиевых риолитов на примере эпитермальных золото-серебряных месторождений Дальнего Востока // Тихоокеанская геология. 2006. Т. 25 . № 6. C. 30-39].

Munhá J., Fyfe W.S., Kerrich R., 1980. Adularia, the characteristic mineral of felsic spilites. Contributions to Mineralogy and Petrology 75 (1), 15-19. https://doi.org/10.1007/BF00371885.

Naumov V.B., Kovalenko V.I., Dorofeeva V.A., Yarmolyuk V.V., 2004. Average concentrations of major, volatile, and trace elements in magmas of various geodynamic settings. Geochemistry International 42 (10), 977-987.

Nekvasil H., 1992. Feldspar crystallisation in felsic magmas: a review. Transactions of The Royal Society of Edinburgh Earth and Environmental Science 83 (1-2), 399-407. https://doi.org/10.1017/S0263593300008063.

Petrographic Code of Russia, 2009. Magmatic, Metamorphic, Metasomatic, and Impact Formations. VSEGEI Press, Saint-Petersburg, 200 p. (in Russian) [Петрографический кодекс России. Магматические, метаморфические, метасоматические, импактные образования. Санкт-Петербург: Издательство ВСЕГЕИ, 2008. 200 с.].

Philpotts A.R., Asher P.M., 1993. Wallrock melting and reaction effects along the Higganum diabase dike in Connecticut: contamination of a continental flood basalt feeder. Journal of Petrology 34 (5), 1029-1058. https://doi.org/10. 1093/petrology/34.5.1029.

Polovinkina Yu.I., 1966. Structures and Textures of Igneous and Metamorphic Rocks. Part 2. Volume II. Nedra, Moscow, 272 p. (in Russian) [Половинкина Ю.И. Структуры и текстуры изверженных и метаморфических горных пород. Часть 2. Том II. М.: Недра, 1966. 272 с.].

Popov V.S., Nikolaenko Yu.S., 1988. On the origin of ultrapotassic rhyolite. Proceedings of the All-Union Mineralogical Society 117 (3), 294-304 (in Russian) [Попов B.С., Николаенко Ю.С. О происхождении ультракалиевых риолитов // Записки Всесоюзного минералогического общества. 1988. Т. 117. № 3. С. 294-304].

Posokhov V.F., Shadaev M.G., Litvinovsky B.A., Khubanov V.B., 2005. Rb-Sr age and sequence of formation of granitoids of the Khorinka volcanoplutonic structure in the Mongolo-Transbaikalian belt. Geologiya i Geofizika (Russian Geology and Geophysics) 46 (6), 625-632.

Putirka K.D., Mikaelian H., Ryerson F., Shaw H., 2003. New clinopyroxene-liquid thermobarometers for mafic, evolved, and volatile-bearing lava compositions, with applications to lavas from Tibet and the Snake River Plain, Idaho. American Mineralogist 88 (10), 1542-1554. https://doi.org/10.2138/am-2003-1017.

Ramakrishnan M., Bhattacharyya S., 1985. Contact metamorphic granophyres of partial melting origin adjacent to dolerite dykes in Karnataka. Journal of Geological Society of India 26 (2), 95-102.

Reichow M.K., Litvinovsky B.A., Parrish R.R., Saunders A.D., 2010. Multi-stage emplacement of alkaline and peralkaline syenite-granite suites in the Mongolian-Transbaikalian belt, Russia: Evidence from U-Pb geochronology and whole rock geochemistry. Chemical Geology 273 (1-2), 120-135. https://doi.org/10.1016/j.chemgeo.2010.02.017.

Rock N.M.S., 1984. Nature and origin of calc-alkaline lamprophyres: minettes, vogesites, kersantites and spessartites Transactions of The Royal Society of Edinburgh - Earth and Environmental Science 74 (4), 193-227. https://doi. org/10.1017/S0263593300013663.

Rozinov M.I., 1967. On reaction ratios of quartz and feldspar from pegmatite segregations in the Gusinoozerskaya dike (West Transbaikalia). Geologiya i Geofizika (Russian Geology and Geophysics) 8 (12), 12-21 (in Russian) [Розинов М.И. О реакционных соотношениях кварца и полевого шпата из пегматитовых обособлений Гусиноозерской дайки (Западное Забайкалье) // Геология и геофизика. 1967. Т. 8. № 12. С. 12-21].

Shadaev M.G., 2001. Conditions of crystallization of alkaline basalt magmas during formation of the Gusinoozerskaya dike (Transbaikalia). Proceedings of the All-Russian Mineralogical Society 130 (1), 34-48 (in Russian) [Шадаев М.Г. Условия кристаллизации щелочно-базальтовых магм при формировании Гусиноозерской дайки (Забайкалье) // Записки Всероссийского минералогического общества. 2001. Т. 130. № 1. С. 34-48].

Sharp Z.D., 1990. A laserbased microanalytical method for the in situ determination of oxygen isotope ratios of silicates and oxides. Geochimica et Cosmochimica Acta 54 (5), 1353-1357. https://doi.org/10.1016/0016-7037(90) 90160-M. 
Sisson T.W., Grove T.L., 1993. Experimental investigations of the role of $\mathrm{H}_{2} \mathrm{O}$ in calc-alkaline differentiation and subduction zone magmatism. Contributions to Mineralogy and Petrology 113 (2), 143-166. https://doi.org/10.1007/ BF00283225.

Sokolova E.N., Smirnov S.Z., 2014. Infuence of fluid phase on composition of rare-metal granite magma: original of ongonites of the East-Kalguty dike belt. In: Granites and Earth's evolution: granites and continental crust. Proceedings of the 2nd International Geological Conference. Publishing House of SB RAS, Novosibirsk, p. 191-193.

Sokolova E.N., Smirnov S.Z., Astrelina E.I., Annikova I.Yu., Vladimirov A.G., Kotler P.D., 2011. Ongonite-elvan magmas of the Kalguty ore-magmatic system (Gorny Altai): composition, fluid regime, and genesis. Russian Geology and Geophysics 52 (11), 1378-1400. https://doi.org/10.1016/j.rgg.2011.10.017.

Stuart D.B., 1983. Formation of silica-rich potassium vitreous rocks. In: H. Yoder (Ed.), Evolution of igneous rocks. Mir, Moscow, p. 332-343 (in Russian) [Стюарт Д.Б. Образование богатых кремнеземом калиевых стекловатых пород // Эволюция изверженных пород / Ред. Х. Йодер. М.: Мир, 1983. С. 332-343].

Tsygankov A.A., Khubanov V.B., Filimonov A.V., 2010. Bimodal volcanogenic and subvolcanic associations of West Transbaikalia ( $\mathrm{Pz}_{3}-\mathrm{Mz}$ ): Magma sources, evolution, geodynamics. Litosfera (Lithosphere) (3), 78-86 (in Russian) [Цыганков А.А., Хубанов В.Б., Филимонов А.В. Бимодальные вулканогенные и субвулканические ассоциации Западного Забайкалья $\left(\mathrm{Pz}_{3}-\mathrm{Mz}\right):$ источники магм, эволюция, геодинамика // Литосфера. 2010. № 3. C. 78-86].

Tsygankov A.A., Khubanov V.B., Travin A.V., Lepekhina E.N., Burmakina G.N., Antsiferova T.N., Udoratina O.V., 2016. Late Paleozoic gabbroids of western Transbaikalia: U-Pb and Ar-Ar isotopic ages, composition, and petrogenesis. Russian Geology and Geophysics 57 (5), 790-808. https://doi.org/10.1016/j.rgg.2015.09.019.

Tuttle O.F., Bowen N.L., 1958. Origin of granite in the light of experimental studies in the system $\mathrm{NaAlSi}_{3} \mathrm{O}_{8}-\mathrm{KAlSi}_{3} \mathrm{O}_{8}-$ $\mathrm{SiO}_{2}-\mathrm{H}_{2} \mathrm{O}$. Geological Society of America Memoirs, vol. 74, 153 p. https://doi.org/10.1130/MEM74-p1.

Vladimirov A.G., Annikova I.Yu., Antipin V.S., 2007. Ongonite-elvan magmatism of Southern Siberia. Litosfera (Lithosphere) (4), 21-40 (in Russian) [Владимиров А.Г., Анникова И.Ю., Антипин В.С. Онгонит-эльвановый магматизм Южной Сибири // Литосфера. 2007. № 4. С. 21-40].

Vorontsov A.A., Yarmolyuk V.V., Ivanov V.G., Nikiforov A.V., 2002. Late Mesozoic magmatism in the Dzhida sector of the Western Transbaikalia rift zone: evolutionary stages, associations, and sources. Petrology 10 (5), 448-468.

Yarmolyuk V.V., Budnikov S.V., Kovalenko V.I., Antipin V.S., Goreglyad A.V., Sal'nikova E.B., Kotov A.B., Kozakov I.K., Kovach V.P., Yakovleva S.Z., Berezhnaya N.G., 1997. Geochronology and geodynamic setting of the Angara Vitim batholith. Petrology 5 (5), 401-414.

Yarmolyuk V.V., Ivanov V.G., Kovalenko V.I., 1998. Sources of intraplate magmatism of Western Transbaikalia in the Late Mesozoic-Cenozoic: trace-element and isotope data. Petrology 6 (2), 101-123.

Yarmolyuk V.V., Kovalenko V.I., 1991. Riftogenic Magmatism of Active Continental Margins and Its Ore-Bearing Capacity. Nauka, Moscow, 263 p. (in Russian) [Ярмолюк В.В., Коваленко В.И. Рифтогенный магматизм активных континентальных окраин и его рудоносность. М.: Наука, 1991. 263 с.].

Zanvilevich A.N., Litvinovsky B.A., 1996. Disequilibrium melting and magma mixing in bimodal hybrid dikes of the Malo-Khamardaban volcanotectonic structure, Transbaikalia. Petrology 4 (4), 342-361.

Zanvilevich A.N., Litvinovsky B.A., Shadaev M.G., 1988. Metastable melting of granites in the basaltic melt. Proceedings of the All-Union Mineralogical Society 117 (6), 648-659 (in Russian) [Занвилевич А.Н., Литвиновский Б.А., Шадаев М.Г. Метастабильное плавление гранитов в базальтовом расплаве // Записки Всесоюзного минералогического общества. 1988. Т. 117. № 6. С. 648-659].

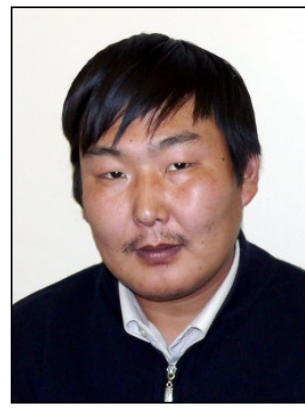

Хубанов Валентин Борисович, канд. геол.-мин. наук, с.н.с.

Геологический институт СО РАН

670047, Улан-Удэ, ул. Сахьяновой, 6а, Россия

Бурятский государственный университет 670000, Улан-Удэ, ул. Смолина, 24a, Россия

$\triangle$ e-mail: khubanov@mail.ru

Khubanov, Valentin B., Candidate of Geology and Mineralogy, Senior Researcher

Geological Institute, Siberian Branch of RAS

6a Sakhyanova street, Ulan-Ude 670047, Russia

Buryat State University

24a Smolin street, Ulan-Ude 670000, Russia

凶e-mail: khubanov@mail.ru 

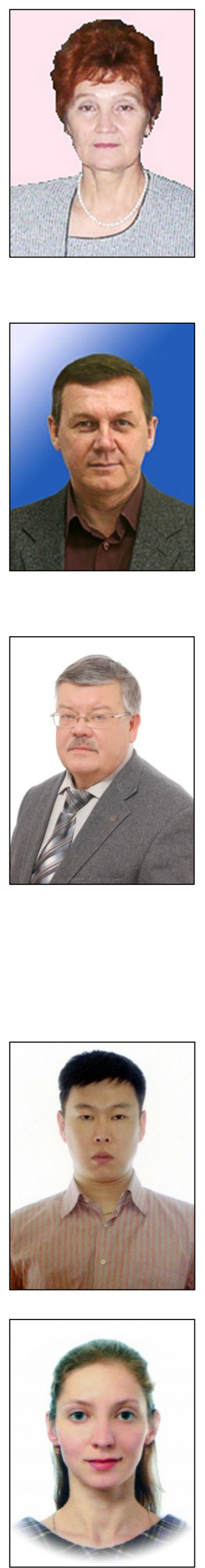

Врублевская Татьяна Тимофеевна, канд. геол.-мин. наук, с.н.с.

Геологический институт СО РАН

670047, Улан-Удэ, ул. Сахьяновой, 6а, Россия

Бурятский государственный университет

670000, Улан-Удэ, ул. Смолина, 24a, Россия

e-mail: vrublevskayatt@rambler.ru

Vrublevskaya, Tatiana T., Candidate of Geology and Mineralogy, Senior Researcher

Geological Institute, Siberian Branch of RAS

6a Sakhyanova street, Ulan-Ude 670047, Russia

Buryat State University

24a Smolin street, Ulan-Ude 670000, Russia

e-mail: vrublevskayatt@rambler.ru

Цыганков Андрей Александрович, докт. геол.-мин. наук, директор

Геологический институт СО РАН

670047, Улан-Удэ, ул. Сахьяновой, 6а, Россия

Бурятский государственный университет

670000, Улан-Удэ, ул. Смолина, 24a, Россия

e-mail: tsygan@gin.bscnet.ru

Tsygankov, Andrei A., Doctor of Geology and Mineralogy, Director

Geological Institute, Siberian Branch of RAS

6a Sakhyanova street, Ulan-Ude 670047, Russia

Buryat State University

24a Smolin street, Ulan-Ude 670000, Russia

e-mail: tsygan@gin.bscnet.ru

Владимиров Александр Геннадьевич, докт. геол.-мин. наук, г.н.с., профессор

Институт геологии и минералогии им. В.С. Соболева СО РАН

630090, Новосибирск, просп. Академика Коптюга, 3, Россия

Новосибирский государственный университет

630090, Новосибирск, ул. Пирогова, 2, Россия

Томский государственный университет

634050, Томск, просп. Ленина, 50, Россия

e-mail: vladimir@igm.nsc.ru

Vladimirov, Aleksander G., Doctor of Geology and Mineralogy, Chief Researcher, Professor

V.S. Sobolev Institute of Geology and Mineralogy, Siberian Branch of RAS

3 Academician Koptyug ave, Novosibirsk 630090, Russia

Novosibirsk State University

2 Pirogov street, Novosibirsk 630090, Russia

Tomsk State University

50 Lenin ave, Tomsk 634050, Russia

e-mail: vladimir@igm.nsc.ru

\section{Буянтуев Молон Димитович, м.н.с.}

Геологический институт СО РАН

670047, Улан-Удэ, ул. Сахьяновой, 6а, Россия

e-mail: molon2@rambler.ru

Buyantuev, Molon D., Junior Researcher

Geological Institute, Siberian Branch of RAS

6a Sakhyanova street, Ulan-Ude 670047, Russia

e-mail: molon2@rambler.ru

Соколова Екатерина Николаевна, канд. геол.-мин. наук, н.с.

Институт геологии и минералогии им. В.С. Соболева СО РАН 630090, Новосибирск, просп. Академика Коптюга, 3, Россия

e-mail: ekaterina@igm.nsc.ru

Sokolova, Ekaterina N., Candidate of Geology and Mineralogy, Researcher

V.S. Sobolev Institute of Geology and Mineralogy, Siberian Branch of RAS

3 Academician Koptyug ave, Novosibirsk 630090, Russia

e-mail: ekaterina@igm.nsc.ru 


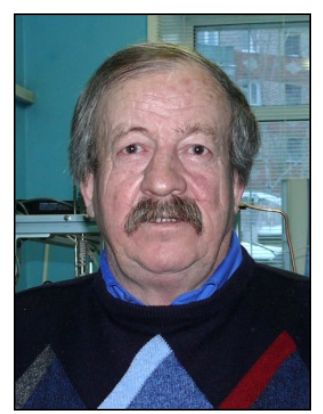

Посохов Виктор Федорович, с.н.с.

Геологический институт СО РАН

670047, Улан-Удэ, ул. Сахьяновой, 6а, Россия

e-mail: vitaf1@yandex.ru

Posokhov, Victor F., Senior Researcher

Geological Institute, Siberian Branch of RAS

6a Sakhyanova street, Ulan-Ude 670047, Russia

e-mail: vitaf1@yandex.ru

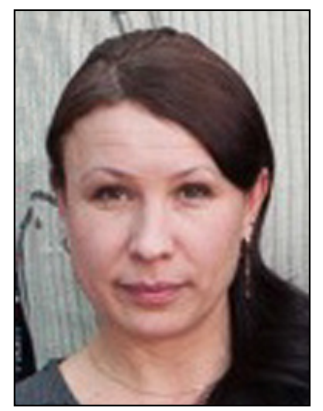

Хромова Елена Александровна, м.н.с.

Геологический институт СО РАН

670047, Улан-Удэ, ул. Сахьяновой, 6а, Россия

e-mail: lena.khromova.00@mail.ru

Khromova, Elena A., Junior Researcher Geological Institute, Siberian Branch of RAS

6a Sakhyanova street, Ulan-Ude 670047, Russia

e-mail: lena.khromova.00@mail.ru 